\title{
ENVISIONING INDIGENOUS COMMUNITY COURTS TO REALIZE JUSTICE IN CANADA FOR FiRST NATIONS
}

\author{
ANGELIQUE EAGLEWOMAN \\ (WAMBDI A. WAS'TEWINYAN) ${ }^{*}$
}

\begin{abstract}
Recognition continues to grow both within Canada, as well as the wider worldwide community, of the unique issues facing Indigenous people within Canada's justice system. We see this in the recent wholesale adoption by the Canadian Government of the United Nations Declaration on the Rights of Indigenous Peoples, as well as the Truth and Reconciliation Commission Calls to Action.

This article examines the potential development of a system of Indigenous community courts as a way to end colonial suppression of Indigenous self-governance. The article suggests as a model for these courts the tribal courts in the United States, as a means by which Indigenous peoples can re-instate Indigenous law and legal principles.
\end{abstract}

\section{TABLE OF CONTENTS}

I. INTRODUCTION . . . . . . . . . . . . . . . . . . . . . . . . . . . . 670

II. CURRENT CRITICAL ISSUES IN THE CANADIAN JUDICIARY For AbORIGINAL PEOPLES . . . . . . . . . . . . . . . . . . . . 672

A. Systemic Racism Against Aboriginal Peoples in CRiminal and Child Welfare Law . . . . . . . . . . 673

B. AtTEMPTS AT CRiminal Sentencing ReForm For Aboriginal Peoples in CANAdian Courts . . . . . . . . . . 675

C. SPecialized Provincial Courts Utilizing Healing Plans in Sentencing . . . . . . . . . . . . . . . . . . 678

D. The Problems With Fly-IN COURTS IN REMOTE First NATION RESERVES IN NORTHERN ONTARIO . . . . . . . . . . 680

III. ATtEMPTS AT STEMMING THE TIDE OF ABORIGINAL CHILDREN IN CARE . . . . . . . . . . . . . . . . . . . 683

A. THE ABORIGinal CHILd WelFare HUMAN RigHTS CRISIS IN CANADA . . . . . . . . . . . . . . . . . . . . . 684

B. IMPROPER APPLICATION OF THE "BEST INTERESTS OF THE CHILD" STANDARD BY COURTS . . . . . . . . . . . . . . 685

IV. A MOdEL: DEVELOPMENT AND OPERATION OF TRIBAL Courts IN THE United States $\ldots \ldots \ldots \ldots \ldots \ldots \ldots . \ldots 66$

A. Similarities Towards Indigenous Relations in Canadian and United States Policy . . . . . . . . . . 686

B. The OsCillation of United States Indian Policy ERAS . . . . . 687

C. Establishment of Tribal Courts In the United StATES . . . . 689

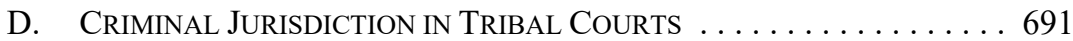

Dean of the Bora Laskin Faculty of Law at Lakehead University, citizen of the Sisseton-Wahpeton Dakota Oyate of the Lake Traverse Reservation in South Dakota. This article is dedicated to the Indigenous law students and allies who seek to reform the Canadian legal framework to allow for the full realization of self-governance to re-emerge for First Nations, Métis, and Inuit peoples. I would also like to thank my research assistant, Jonathan Williams, for his hard work and legal research in support of this article. All views expressed in this article are mine alone as are any errors. 
E. THE INDIAN CHILD WELFARE ACT OF 1978

AND THE ROLE OF TRIBAL COURTS . . . . . . . . . . . . . . . . . . . . 693

V. ESTABLISHING A SySTEM OF INDIGENOUS COMMUNITY COURTS . . . . . . 697

A. Proposed Organization AND JURISDiCtion

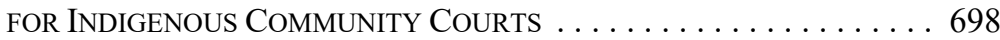

B. TRAILBLAZING THE WAY FOR

INDIGENOUS COMMUNITY COURTS . . . . . . . . . . . . . . . 699

C. FUNDING AND SUPPORT FOR

INDIGENOUS COMMUNITY COURTS . . . . . . . . . . . . . . . 704

D. Swinging The Pendulum in CANADA

TO SUPPORT FIRST NATION SOVEREIGNTY . . . . . . . . . . 705

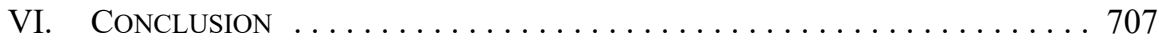

There can be no peace or harmony unless there is justice.

- Royal Commission on Aboriginal Peoples (1996)

\section{INTRODUCTION}

Through European colonization in North America, the time-honored rule of law, or good way of life, ${ }^{1}$ in Indigenous communities was displaced with external forums and processes, primarily from the British juridical traditions. In contemporary Canada, the use of external laws as a tool of colonization and the injustice experienced by Aboriginal peoples in Canadian courts has been the focus of media attention, policy papers, and legal reports for decades. The Canadian justice system is viewed by many as external and a means of subjugation for First Nation, Métis, and Inuit peoples. ${ }^{2}$ As the Canadian government has attempted to come to terms with the long shadow cast by colonization, Indigenous peoples are consistently and increasingly calling for the ability to fully self-govern and reinstate Indigenous law and legal principles. ${ }^{3}$

In the Dakota tradition, this is taught as walking the Canku Duta Was'te (Good Red Road) and following the teaching of Mitakue Oyasin (We Are All Related). In the Anishnaabe tradition, Mino Bimaadiziwin is living the Good Way of Life. Every Indigenous people have a concept for following the values and teachings of living a good life as a human being on Mother Earth.

2 See The Advocates' Society, The Indigenous Bar Association \& The Law Society of Ontario, "Guide for Lawyers Working with Indigenous Peoples" (8 May 2018), online: <https://www.advocates. $\mathrm{ca} /$ Upload/Files/PDF/Advocacy/BestPracticesPublications/Guide_for_Lawyers_Working_with_Indi genous_Peoples_may16.pdf $>$ ("[a]s the law has developed in Canada, many Indigenous peoples have grown to distrust Canadian legal systems and the professionals working within them. From Indigenous perspectives, the law was only designed and meant to be enforced against Indigenous peoples, and never designed or meant to serve them,"s 2.2.3).

3 See John Borrows, "Indigenous Legal Traditions in Canada" (2005) 19 Wash UJL \& Pol'y 167 at 208-209:

Indigenous governance would enjoy greater accountability and legitimacy if their own institutions were able to to resolve their disputes. The power of Aboriginal people to judge and hold their own members accountable for their actions is an Aboriginal right that was integral to First Nations communities prior to the arrival of Europeans. Further, this right has not been extinguished, and can be exercised in a contemporary form. 
In 2015, the Canadian Truth and Reconciliation Commission (TRC) issued its 94 Calls to Action to support reconciliation between the settler-nation of Canada and Aboriginal peoples ${ }^{4}$ in their homelands. ${ }^{5}$ This monumental undertaking has introduced a new standard in global relations as setting forth concrete and aspirational goals to heal a legacy of colonialism, genocide, the abduction of generations of Aboriginal children to residential schools, historical trauma, and the entrenched poverty conditions experienced within reserves and Indigenous communities. TRC Call to Action 42 provides staunch support for Indigenous justice systems to be reinstated and supported in Canada:

We call upon the federal, provincial, and territorial governments to commit to the recognition and implementation of Aboriginal justice systems in a manner consistent with the Treaty and Aboriginal rights of Aboriginal peoples, the Constitution Act, 1982, and the United Nations Declaration on the Rights of Indigenous Peoples, endorsed by Canada in November of $2012 .^{6}$

This ringing call for recognition of Indigenous justice systems in Canada speaks directly to the ending of colonial suppression of Indigenous self-governance.

The Truth and Reconciliation Commission's Calls to Action make reference to the United Nations Declaration on the Rights of Indigenous Peoples ${ }^{7}$ which provides a framework for reconciliation. An important moment has arrived in Canada where the TRC Calls to Action and the UNDRIP are solidly on the table for consideration at the highest levels of government, in the public discourse, and within Aboriginal communities. To make the most of this moment, this article will provide a discussion on Aboriginal justice systems in Canada and the need to reinvigorate traditional methods with aspects of modern forums that are Aboriginal-based and administered. The UNDRIP articles 34 and 40 support the rights of Indigenous peoples to develop and maintain their juridical systems and to access fair procedures for dispute resolution informed by Indigenous "customs, traditions, rules and legal systems." courts.

This article will first discuss the current issues in the Canadian judiciary for Aboriginal peoples with a focus on criminal law and child welfare practices. Tracing the response to the crisis of overincarceration of Aboriginal peoples, the Supreme Court of Canada has laid out principles on appropriate sentencing of Aboriginal offenders. Another response has been to develop specialized provincial courts for proper sentencing of Aboriginal peoples. Despite these efforts, overincarceration continues to increase. Next, the statistics on the over-removal 4 "Aboriginal" is a legal term of art as defined in the Constitution Act, 1982, being Schedule B to the
Canada Act 1982 (UK), 1982, c 11 ("[i]n this Act, "aboriginal peoples of Canada' includes the Indian, Inuit and Métis peoples of Canada," s 35(2)).

5 Truth and Reconciliation Commission of Canada, Canada's Residential Schools: Reconciliation, vol 6 (Winnipeg: TRC, 2015) at 223-41 [TRC, Vol 6].

$6 \quad$ Ibid at Recommendation 42.

United Nations Declaration on the Rights of Indigenous Peoples, GA Res 61/295, UNGAOR, 61st Sess, Sup No 53, UN Doc A/61/295 (2007), online: <www.un.org/esa/socdev/unpfii/documents/DRIPS en.pdf $>$ [UNDRIP]. See Indigenous and Northern Affairs Canada, "United Nations Declaration on the Rights of Indigenous Peoples," online: <www.aadnc-aandc.gc.ca/eng/1309374407406/1309374458958> ("[i]n May 2016, the Minister of Indigenous and Northern Affairs announced Canada is now a full supporter, without qualification, of the declaration"). 
of Aboriginal children from their homes will be discussed and the role of the Canadian judiciary.

To provide an example from the United States, tribal courts have been instrumental in providing culturally appropriate dispute resolution forums in Indigenous communities, particularly for domestic issues such as child welfare and for criminal conduct occurring on reservations. By comparing the growth of US tribal ourts and the beginnings of justice systems that are formally recognized for Aboriginal peoples in Canada, the article will provide insight and recommendations to address the need for Aboriginal peoples to implement their own judicial forums. Next, the efforts of First Nations through section 107 of the Indian $\mathrm{Act}^{9}$ Native Justices of the Peace Program will be discussed. A review of the Court of Kahanwa:ke and the Akwesasne Court as trailblazers for more Indigenous courts in Canada follows. The article will conclude with a recommendation for the creation of a system of Indigenous community courts and the necessary steps to realize Indigenous-led justice initiatives, including appropriate recognition of jurisdiction and proper funding.

\section{CURRENT CRITICAL ISSUES IN THE Canadian Judiciary for Aboriginal Peoples}

Eighteen of the TRC Calls to Action form a section on justice for Aboriginal peoples. ${ }^{10}$ These Calls to Action highlight concerns over criminal investigations, ${ }^{11}$ the overrepresentation of Aboriginal adults and youth in custody, ${ }^{12}$ appropriately addressing the needs of inmates, ${ }^{13}$ the collection of data and reporting on victimization of Aboriginal peoples,${ }^{14}$ the need for funding of programs and services for Aboriginal peoples experiencing victimization, ${ }^{15}$ and the call to "commit to the recognition and implementation of Aboriginal justice systems." 16

As the Calls to Action attest, Indigenous Canada is alarmed regarding the overrepresentation of Aboriginal peoples in custody, the lack of culturally appropriate judicial forums, and the need for alternative methods of resolving issues arising in the lives of Aboriginal adults and youth. According to correctional statistics for 2014-2015, Aboriginal peoples comprising only 3 percent of the Canadian population accounted for 25 percent of provincial and territorial custody admissions and 22 percent of federal correctional admissions. ${ }^{17}$ Female Aboriginal adults showed the greatest overrepresentation as 38 percent of the provincial and territorial correctional admissions and 31 percent of federal custodial admissions. ${ }^{18}$ Aboriginal youth were overrepresented as well with 33 percent of custodial admissions from nine jurisdictions where the Aboriginal youth

RSC 1985, c I-5.

Truth and Reconciliation Commission of Canada, Canada's Residential Schools: The Legacy, vol 5 (Montreal: McGill-Queen's University Press, 2015) at Recommendations 25-42 [TRC, Vol 5].

Ibid at Recommendation 25.

Ibid at Recommendations 30, 38 .

Ibid at Recommendations 34-36.

Ibid at Recommendation 39.

Ibid at Recommendation 40.

Ibid at Recommendation 42.

Statistics Canada, "Adult Correctional Statistics in Canada, 2014/2015" by Julie Reitano, online: $<$ www. statcan.gc.ca/pub/85-002-x/2016001/article/14318-eng.htm>.

Ibid. 
population comprised 7 percent of the total youth population. ${ }^{19}$ In comparison to the 42 percent of non-Indigenous youth who were admitted to custody, 52 percent of Aboriginal youth were admitted to the corrections system with a higher proportion of female Aboriginal youth at 44 percent. $^{20}$

In 2015-2016, statistics for the provincial and territorial custody admissions for Aboriginal adults were 26 percent and for federal correctional admissions, 28 percent, representing a 6 percent increase for admission to federal custody from the previous year. ${ }^{21}$ For Aboriginal females the overrepresentation numbers were the same as the prior year with 38 percent of provincial and territorial custodial admissions and 31 percent of the federal system. ${ }^{22}$ For Aboriginal youth, the numbers increased in 2015-2016 to 35 percent for those admitted to correctional facilities out of a population of 7 percent of total youth. ${ }^{23}$ Likewise compared to the 44 percent of non-Aboriginal youth admitted to custody, 54 percent of Aboriginal youth were admitted to correctional services with the overrepresentation of female Aboriginal youth at 43 percent. ${ }^{24}$ These are alarming statistics regarding the criminalization of Aboriginal peoples and they depict systemic racism in the Canadian judicial system.

\section{A. Systemic Racism Against Aboriginal Peoples in CRIMINAL AND CHILd WELFARE LAW}

These figures demonstrate that a significant portion of the Aboriginal population in Canada has experienced incarceration and the rates of incarceration are on the rise. Systemic racism, defined as discrimination of a particular group of people based on using a system's normative framework, is one lens to view this situation through. Within a system where racism has become the norm, the group being discriminated against is ascribed with negative characteristics allowing for the normative group to dehumanize and punish the individuals belonging to the group by viewing them as lesser or inferior. From the 1995 Report of the Commission on Systemic Racism in the Ontario Criminal Justice System, the following definition of systemic racism is provided:

By systemic racism we mean the social production of racial inequality in decisions about people and in the treatment they receive. Racial inequality is neither natural nor inherent in humanity. On the contrary, it is the result of a society's arrangement of economic, cultural and political life. It is produced by the combination of:

- social constructions of races as real, different and unequal (racialization);

Statistics Canada, "Youth Correctional Statistics, 2014/2015" by the Correctional Services Program, online: <www.statcan.gc.ca/pub/85-002-x/2016001/article/14317-eng.htm>.

Ibid.

21 Statistics Canada, “Adult Correctional Statistics in Canada, 2015/2016” by Julie Reitano, online: <www. statcan.gc.ca/pub/85-002-x/2017001/article/14700-eng.htm>.

22 Ibid.

23 Statistics Canada, "Youth Correctional Statistics in Canada, 2015/2016" by Jamil Malakieh, online: $<$ www. statcan.gc.ca/pub/85-002-x/2017001/article/14702-eng.htm>. Ibid. 
- the norms, processes and service delivery of a social system (structure); and

- the actions and decisions of people who work for social systems (personnel). ${ }^{25}$

Thus, the normative group ascribes to itself views of superiority and moral virtues in passing judgment on the discriminated-against group. Further, judges in such a normative group are able to ascribe to an individual from a discriminated-against group characteristics of low morals, untrustworthiness, chronic addictions, and the worst sorts of behaviours, mannerisms, and motives.

Within judicial systems, a broad discretion is exercised by judges. This discretion can result in a warning when a judge considers an alleged offender to have made a minor error in judgment. This discretion can also lead to long term incarceration when a judge determines that the public is at risk, requiring removal of an individual from society for a set period of time. For Aboriginal peoples, Canadian judges hand down the harshest sentences, lawyers spend less time with the accused, and it is generally noted from reports and inquiries dating back to 1967 that the criminal justice system has failed Aboriginal peoples. ${ }^{26}$

From the discretion of police to apprehend, to the discretion of the Crown Attorney to lay charges, to the discretion of a jury to convict or acquit, to the discretion of a judge to sentence, the consequences of systemic racism have led to the current crisis as evidenced in the overrepresentation of Aboriginal peoples in prisons and jails. ${ }^{27}$ Taken together with the early role of Canadian courts to prosecute Aboriginal peoples who advocated for their homelands and lifeways, the distrust by Aboriginal peoples of the Canadian criminal justice system has roots in both the legacy of colonialism and the current lived experience of Aboriginal people. Examples of the use of police force in Aboriginal rights demonstrations do not follow the general rules for police action to ensure peaceable demonstrations. "Rather, in these cases, the police are used to intervene on the side of the government and to crush or quash the protest on the assumption that the claim of rights being advanced is wrong prior to any determination by the courts as to the ultimate validity of the claim itself." ${ }^{28}$ Thus, Aboriginal peoples have been subjected to force, violence, and the inability to assert basic human rights under the present legacy of colonialism as enforced by police and the mainstream court systems. ${ }^{29}$ Systemic Racism in the Ontario Criminal Justice System (Ottawa: Queen's Printer for Ontario, December 1995) at 39, online: <www.ontla.on.ca/library/repository/mon/25005/185733.pdf> [emphasis in original].

26 See Royal Commission on Aboriginal Peoples, Bridging the Cultural Divide: A Report on Aboriginal People and Criminal Justice in Canada (Ottawa: Ministry of Supply and Services, 1996) at 26-32. Ibid at 33-39.

28 Jonathan Rudin, Aboriginal Peoples and the Criminal Justice System (Toronto: Ipperwash Inquiry, 2005) at 30, online: <https://www.attorneygeneral.jus.gov.on.ca/inquiries/ipperwash/policy_part/ research/pdf/Rudin.pdf $>$. Ibid. 


\section{B. Attempts at Criminal Sentencing Reform for Aboriginal Peoples in Canadian Courts}

Several measures have been implemented in response to the high incarceration rate of Aboriginal peoples in Canada, but they currently all involve oversight from the mainstream provincial and federal court systems. In 1996, the reform of criminal sentencing law by instructing judges to consider alternatives to incarceration, particularly for Aboriginal peoples, was added to the Canadian Criminal Code as section $718.2(\mathrm{e}) .^{30}$ Ironically, the incarceration rates for non-Aboriginal peoples has decreased while the incarceration rates for Aboriginal peoples has increased in the subsequent decades and continue to rise. ${ }^{31}$

Following the enactment of the remedial section 718.2(e), the Supreme Court of Canada handed down guidance on interpretation and implementation of the section in the $R$. $v$. Gladue $^{32}$ decision of 1999 . The decision set out an affirmative obligation on judges to obtain pre-sentencing reports on Aboriginal offenders and to sentence appropriately, consistent with the remedial nature of section 718.2(e). ${ }^{33}$ The Supreme Court stressed: "sentencing judges should pay particular attention to the circumstances of aboriginal offenders because those circumstances are unique, and different from those of non-aboriginal offenders." ${ }^{34}$ In reviewing the legislative history for enactment of section 718.2(e), the Supreme Court found the section "was directed, in particular, at reducing the use of prison as a sanction, at expanding the use of restorative justice principles in sentencing, and at engaging in both of these objectives with a sensitivity to aboriginal community justice initiatives when sentencing aboriginal offenders." 35

Next, the Supreme Court reviewed the disturbing reality of the excessive incarceration of Aboriginal peoples at both the federal and provincial levels and noted that multiple commissions and inquiries had been previously conducted on the issue. ${ }^{36}$ Citing to its prior decision in $R . v$. Williams, the Supreme Court reiterated that racism and unconscious bias towards Aboriginal peoples has permeated the criminal justice system in Canada. ${ }^{37}$ The systemic and background factors that sentencing judges should take into consideration for Aboriginal peoples include the experiences of colonialism that have been imposed on Aboriginal ancestors to the present day realities. The Supreme Court provided a list of factors, including "poverty, substance abuse, lack of education, and the lack of employment opportunities." ${ }^{38}$ In discussing the imposition of incarceration as a sentence for Aboriginal peoples, the decision stated that Aboriginal peoples are "more adversely affected by incarceration and less likely to be 'rehabilitated' thereby, because the internment milieu is often culturally inappropriate and regrettably discrimination towards them is so often

Criminal Code, RSC 1985, c C-46, s 718.2(e) ("all available sanctions, other than imprisonment, that are reasonable in the circumstances and consistent with the harm done to victims or to the community should be considered for all offenders, with particular attention to the circumstances of Aboriginal offenders").

Wendy Chan \& Dorothy Chunn, Racialization, Crime, and Criminal Justice in Canada (Toronto: University of Toronto Press, 2014) at 97.

[1999] 1 SCR 688.

Ibid at para 66.

Ibid at para 37 [emphasis in original].

Ibid at para 48 .

Ibid at paras 58-60.

Ibid at para 61, citing $R v$ Williams, [1998] 1 SCR 1128 at para 58.

Ibid at para 65 . 
rampant in penal institutions." 39 Recognizing the abysmal reality for Aboriginal peoples who come in contact with the criminal justice system, the Supreme Court turned its attention to restorative justice principles as part of the remedial function of the Criminal Code in section 718 and specifically in section 718.2(e).

Taking note of the development of Aboriginal community sentencing circles and other rehabilitative measures, the Supreme Court encouraged sentencing judges to consider sentencing from an Aboriginal perspective in line with restorative justice principles. ${ }^{40}$ In sum, the Supreme Court's decision was to properly interpret section 718.2(e) and in doing so the requirement for pre-sentencing reports detailing background factors and life experiences for Aboriginal peoples emerged.

Following this decision, "Gladue Reports" have come into play at the sentencing stage for some Aboriginal offenders, however, there has been significant resistance to following the spirit of the Gladue decision in Canadian courts. The systemic racism facing Aboriginal peoples in Canadian courts has not been dismantled through remedial tweaks and suggestions to sentencing judges to view Aboriginal offenders as human beings by bringing their lives and circumstances into the sentencing paradigm.

Subsequent Supreme Court of Canada decisions have continued to instruct the use of Gladue Reports and the proper application of section 718.2(e) by sentencing judges. In $R$. $v$. Ipeelee, ${ }^{41}$ two Aboriginal men were found to have breached Long Term Sentencing Orders (LTSO) and in both cases the Supreme Court was called upon to determine the appropriate sentences for those with lengthy criminal records. ${ }^{42}$ The Supreme Court instructed sentencing judges to take judicial notice of factors affecting Aboriginal people in Canadian society. ${ }^{43}$ These factors included "the history of colonialism, displacement, and residential schools and how that history continues to translate into lower educational attainment, lower incomes, higher unemployment, higher rates of substance abuse and suicide, and of course higher levels of incarceration for Aboriginal peoples." ${ }^{4}$

The Supreme Court noted that incarceration rates of Aboriginal peoples had increased following the Gladue decision and sought to address the misapplication and criticisms of the Gladue decision. ${ }^{45}$ Supporting the Gladue decision, the Supreme Court stated that using innovative sentencing that led to the offender taking responsibility and not re-offending was a proper goal for sentencing judges. The twin goals of deterring criminality and rehabilitating offenders were underlying purposes of section 718.2(e), taking into account the circumstances of Aboriginal peoples at sentencing in turn leading to less incarceration. ${ }^{46}$

Ibid at para 68 .

Ibid at paras 71-74.

2012 SCC 13 [Ipeelee].

Ibid at para 1.

Ibid at para 60

Ibid.

Ibid at paras 62-64.

Ibid at para 68 . 
Responding to the criticisms that Aboriginal peoples would receive a discounted sentence based on race, the Supreme Court provided further context for restorative justice principles in sentencing of Aboriginal peoples in Canadian courts. ${ }^{47}$ The decision explained that sentencing judges must determine the circumstances that led to the crime in order to determine moral blameworthiness and for Aboriginal peoples this may include poverty and economic deprivation factors from the pre-sentence reports. ${ }^{48}$ The Supreme Court favourably quoted from an article by Tim Quigley for the point that offenders who are employed are less likely to be incarcerated, whereas Aboriginal peoples who are often unemployed and suffer from lower socio-economic status bear the brunt of harsher sentencing which represents systemic discrimination. ${ }^{49}$

To apply a fit and proper sentence for an Aboriginal person, the sentencing judge must take into account the effectiveness of the sentence from the perspective of Aboriginal peoples, such as taking responsibility, community service, and ordering treatment programs to deter re-offending. ${ }^{50}$ Also, the legacy of colonialism in the Canadian criminal justice system had to be understood as contributing to the rates of incarceration of Aboriginal peoples. ${ }^{51}$ The Supreme Court further stated that sentences would likely be different between an Aboriginal person and a non-Aboriginal person or any two persons, due to their unique backgrounds and circumstances, therefore, sentencing judges must sentence the person before them, not a hypothetical offender. ${ }^{52}$ Other specific guidance from the Supreme Court included that Aboriginal peoples need not prove a causal link between their background and circumstances to the crime committed for the sentencing judge to consider alternatives to incarceration $^{53}$ and Gladue Reports apply to all Aboriginal peoples for all offences and there is no exception for what a judge considers a serious offence. ${ }^{54}$

Over a decade after the Gladue decision, the Supreme Court in Ipeelee observed the uneven and misapplication of the principles set forth to assist sentencing judges. By taking into consideration the background factors and circumstances of Aboriginal peoples, these two decisions from the Supreme Court of Canada were an invitation to view Aboriginal peoples in the criminal justice system as fellow human beings with distinct worldviews that were to be taken into account by judges. Every court in Canada has been expected to serve as a Gladue court for Aboriginal offenders since the decision in 1999. Through the systemic racism lens, the guidance from Gladue and Ipeelee attempted to disrupt the normative framework of criminalizing Aboriginal peoples and condemning them at every phase of the criminal justice system. Tragically, the over-representation of Aboriginal men, women, and

Ibid at paras 70-73.

Ibid at para 73 .

Ibid at para 67, citing Tim Quigley, "Some Issues in Sentencing of Aboriginal Offenders" in Richard Gosse, James Youngblood Henderson \& Roger Carter, eds, Continuing Poundmaker and Riel's Quest: Presentations Made at a Conference on Aboriginal Peoples and Justice (Saskatoon: Purich Publishing, 1994) 269 at $275-76$.

Ipeelee, ibid at para 75 .

Ibid at para 77 .

Ibid at paras 79,86 .

Ibid at paras $84-86$.

Ibid at paras 86-87. 
youth in prisons, jails, and correctional facilities continues to increase in an environment of systemic racism. $^{55}$

\section{Specialized Provincial Courts Utilizing Healing Plans in Sentencing}

Diversion from criminal court proceedings to Crown sanctioned rehabilitative programs is one option that has been and continues to be available to Canadian courts. Another option lies with the push for restorative justice programs created with Indigenous values centered on healing plans. There are a few limited examples of restorative justice systems available to First Nation, Métis, and Inuit peoples and they are all facing systemic underfunding. The handful that are available serve as deferral forums from mainstream provincial court systems. One of the most familiar types of deferrals is to sentencing circles in criminal proceedings. All deferrals are at the discretion of the sentencing judge who may or may not follow recommendations from such forums.

Examples of these type of restorative justice forums are available through the British Columbia judicial system. Under the umbrella of specialized provincial courts, the following are listed: Aboriginal Family Healing Court Conferences, Drug Treatment Court of Vancouver, Downtown Community Court, Domestic Violence Courts, First Nations Court, and Victoria Integrated Court. ${ }^{56}$ The movement in the last few decades to specialized courts to allow for closer contact between those charged with criminal offenses and judicial officials has been heralded in by the efforts of social services and communities seeking fuller attention to misconduct and its symptoms. For those specialized courts serving specifically Aboriginal peoples, the development has been more recent and is an ongoing effort at present.

The specific example of the First Nations Court of New Westminister, as an arm of the provincial system, began in November of 2006 under the supervision of Judge Marion Buller, Mistawasis First Nation of Saskatchewan. ${ }^{57}$ Offenders must self-identify as First Nations, enter a guilty plea to a criminal charge, and the Crown Attorney as prosecutor must consent to the inclusion in First Nations Court. ${ }^{58}$ As a sentencing court, the judge brings in a team to support the First Nations client in developing and monitoring a court-sanctioned healing plan. ${ }^{59}$ The team includes Elders, community service representatives, probation officers, addiction counsellors, and others tailored to the needs of the particular client in a holistic approach. ${ }^{60}$

\footnotetext{
55 For a discussion of the repercussions faced by an Alberta non-Indigenous judge seeking to apply restorative justice concepts to Aboriginal people's criminal cases and changing systemic racism in his courtroom, see generally John Reilly, Bad Judgment: The Myths of First Nations Equality and Judicial Independence in Canada (Victoria: Rocky Mountain Books, 2014).

56 See Provincial Court of British Columbia, "Specialized Courts," online: <www.provincialcourt.bc.ca/ about-the-court/specialized-courts>.

Presentation by Judge Garth Smith in "Aboriginal Justice Systems Conference" (2 March 2018) at $3 \mathrm{~h}: 53 \mathrm{~m}: 22 \mathrm{~s}-4 \mathrm{~h}: 30 \mathrm{~m}: 36 \mathrm{~s}$, online: $<\mathrm{https}: / / \mathrm{www}$. youtube.com/watch?v=dTH0oCd 07Sw\#action=share $>$. Ibid.

Ibid.

Ibid.
} 
Another example is the Elsipogtog Healing to Wellness Court in New Brunswick, established in October 2012, it is a provincially-based specialized court for Elsipogtog Band members who have been charged for crimes in Kent County. ${ }^{61}$ The offender must have an identified issue such as addiction to drugs or alcohol, mental health issue, or intellectual disability or cognitive impairment (such as Fetal Alcohol Spectrum Disorder) ${ }^{62}$ The Healing to Wellness Court (HWC) will not take jurisdiction of cases involving charges with mandatory minimum sentences or violent offences. ${ }^{63}$ The Crown prosecutor determines whether an accused fits within the eligibility criteria and subsequently the pre-court team and the healing team of the court decide whether to admit the accused. ${ }^{64}$ The HWC program is a voluntary undertaking for the participant who must (1) take responsibility for misconduct; and (2) undergo assessment by the primary case manager leading to a recommendation on suitability. ${ }^{65}$ Once accepted, the participant has regular court appearances to monitor the holistic approach and particular healing plan for the person. ${ }^{66}$ Cultural practices may be included in the plan such as attending community events, pow wows, cultural activities, and spiritual activities. ${ }^{67}$

A third example is the Indigenous Peoples Court of Thunder Bay established most recently on 6 March 2017 with presiding Judge Joyce Pelletier of the Fort William First Nation. ${ }^{68}$ The Indigenous Peoples Court employs the model of a sentencing circle derived from the healing circle used since time immemorial in many Indigenous communities ${ }^{69}$ For an accused to be eligible for participation in the Court, he or she must self-identify as First Nations, Métis, or Inuit. ${ }^{70}$ The Crown as prosecutor screens and determines what cases will be referred and the accused must enter a guilty plea. Housed in the Thunder Bay Consolidated Courthouse, the Indigenous Peoples Court holds sessions in a round courtroom with no raised dais and beaded regalia are worn to designate the Elders and the presiding judge. $^{71}$

All of these examples are strides toward changing the criminal law framework from the punitive model to forums where multigenerational abuse, discrimination, and poverty from colonialism can be addressed for individuals and those impacted by their actions in a judicial forum. These specialized courts allow participants time to fulfill healing plans, provide ongoing check-ins with participants, and seek to provide consistent community support and services to change the lifepath for the participant. As blended courts, cultural practices of tradition, Elders, and teachings are mixed with the requirements of the Canadian Criminal Code.

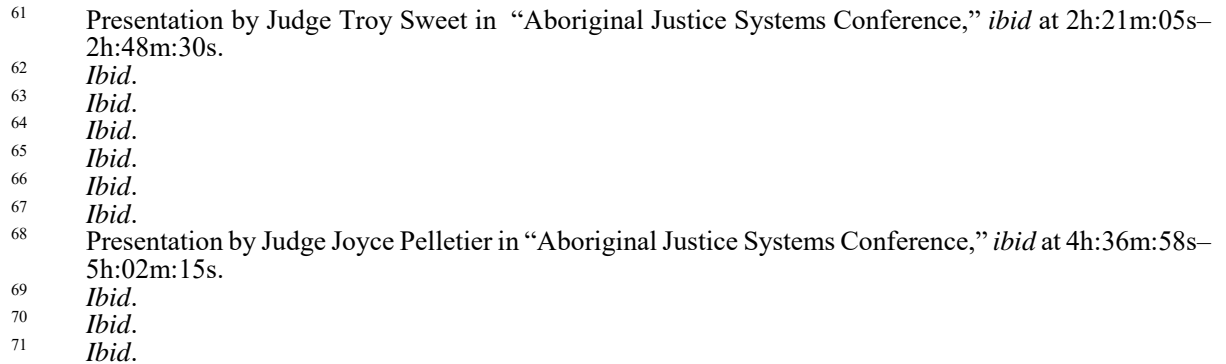


The major drawbacks to specialized provincial courts are that the criterion for participation are narrowly defined, usually the Crown has wide discretion to screen or refer those charged to participate, and the courts are still embedded in the provincial criminal system. As provincial courts, barriers to the operation of these specialized courts may exist, such as lack of funding, lack of acceptance of specialized court processes including resistance by court staff and mainstream court officials, and criticism by practitioners and mainstream community members on healing plans and court practices. While specialized courts represent an important alternative to standard Anglo-Saxon derived court practices where overincarceration is the norm, there are still systemic issues that require a more comprehensive solution.

\section{The Problems With Fly-In Courts in Remote FIRST NATION RESERVES IN NORTHERN ONTARIO}

With the Indian Act of 1876, the reserve system for Indian Bands was ushered in, ${ }^{72}$ resulting in remote reserve communities in Northern Ontario facing severe conditions in terms of quality of life and basic services taken for granted to the south. ${ }^{73}$ Over the last 45 years, infrastructure through road development and greater opportunities for connection with other communities has led to both positive and negative results. ${ }^{74}$ One development has been the expansion of law enforcement services and the concomitant need for judicial forums to address criminal activity. ${ }^{75}$ For First Nations in Northern Ontario, there is an ongoing need for services at all levels of government from treatment programs to justice services to educational and vocational training to mental health and counseling to name a few. ${ }^{76}$

In 2013, a report authored by the Ontario Court Justice and the Ministry of the Attorney General Joint Fly-In Court Working Group was released with recommendations to improve provincial judicial services traveling into remote First Nation communities in Northern Ontario. ${ }^{77}$ Criminal and family law matters are heard in the 29 fly-in courts with court held between two and forty times per year in each court. ${ }^{78}$ The following is a description of the

Indian Act, supra note 9, s 18

See Sonja Puzic, "\$10 for Bag of Potatoes: Northern Ont. Aboriginals Spend More Than Half of Income on Food," CTV News (12 September 2016), online: <https://www.ctvnews.ca/canada/10-for-bag-ofpotatoes-northern-ont-aboriginals-spend-more-than-half-of-income-on-food-1.3068160> ("[Joseph] LeBlanc [a Food Secure Canada board member] said the larger issues facing remote northern communities, such as high suicide rates, poor education and health outcomes, can all be linked to food insecurity").

74 See Ontario Court of Justice and Ministry of the Attorney General Joint Fly-In Court Working Group Report on Fly-In Court Operations (August 2013) at 2, online: <www.ontariocourts.ca/ocj/files/reports/ fly-in.pdf $>$ [Fly-In Court Operations].

$75 \quad$ Ibid.

76 See The Canadian Press, "Lack of Services Contributing to Indigenous Mental Health Crisis: Frontline Workers," CTV News (27 November 2016), online: <https://www.ctvnews.ca/health/lack-of-servicescontributing-to-indigenous-mental-health-crisis-frontline-workers-1.3178797> ("[b]ut among the explanations [for youth suicides] extended - poverty, overcrowded housing, dismal job prospects, widespread alcohol and drug abuse, and family violence - another potential reason simmers silently below the surface of everyday life on many reserves: child sexual abuse"). Fly-In Court Operations, supra note 74. Ibid at 5 . 
arrival of the Ontario Court of Justice and related staff to conduct a fly-in court day at a remote community.

\begin{abstract}
On a typical fly-in court day, the "court party" (which includes the judge, Crown prosecutor, defence or child protection counsel, family counsel, court staff, V/WAP [Victim/Witness Assistance Program] staff, and the police) fly into the community in the morning and fly out at the end of the day. Additionally NAN [Nishnawbe Aski Nation] Legal employs community legal workers in several fly-in communities, who are available to assist the accused persons. For each fly-in court day, at least three chartered aircraft will fly into the community. There is a plane chartered by the Crown's Office and NAN Legal to transport Crown and defence counsel, a police plane, and a plane chartered by MAG [Ministry of the Attorney General] for the judge and court staff. ${ }^{79}$
\end{abstract}

These planes descend into the community and in one fell swoop sentence community members, conduct hearings on probation violations, and determine child protection and placement matters, and then they depart the same day. Further, the impression given to the First Nation community is that external forces are briefly entering the community to impose serious decisions and then abruptly leaving without participating or understanding the consequences of those decisions.

Some of the issues highlighted in the 2013 report led to the following criminal law recommendations: advance days for defence and/or Crown prosecutor meetings with community members involved in court proceedings through the use of videoconferencing prior to the one fly-in court day; ${ }^{80}$ better communication and the filing of designations by defence counsel to appear on behalf of accused persons for court appearances to reduce the number of unnecessary court appearances by the community member; implement the standards of the Youth Criminal Justice Act ${ }^{81}$ section 3(1)(b) and schedule separate sitting days for youth proceedings; and the need for courts to receive timely Gladue Reports as defendants often waive their rights rather than face lengthy incarcerations while the information is collected between court dates. ${ }^{82}$

The Working Group also identified family law and child protection issues and recommendations, such as for MAG to offer the same expanded family law services ${ }^{83}$ that other communities received ${ }^{84}$ for Legal Aid Ontario to improve provision of telephone legal advice services for family law and child protection matters to First Nations people living in fly-in communities; ${ }^{85}$ for MAG to recognize that many First Nations people in remote communities do not have internet access to download forms or instructions for family law filings available to other Ontarians and to provide access and legal advice in remote

Ibid at 6-8. While defence counsel, NAN Legal, and the police were in support of the video advance days, the Crown counsel raised several issues and agreed on a limited scope pilot project in two possible fly-in communities (ibid at 7).

81 SC 2002, c 1.

$82 \quad$ Fly-In Court Operations, supra note 74 at $15-17$.

83 Ibid at 10

$84 \quad$ Ibid (" $[\mathrm{t}]$ hese expanded services include family mediation, an information and referral coordinator to assist with community referrals, and a Mandatory Information Program that family law litigants are required to attend. MAG's service expansion, however, did not take account of the particular needs of fly-in communities" at 10-11).

85 Ibid at 11 . 
communities; ${ }^{86}$ for MAG to adjust requirements on filing documents, personal service, attending Mandatory Information Programs, and swearing affidavits as there are substantial barriers for those in remote communities; for MAG to "ensure persons in fly-in communities are informed in a timely and consistent manner of their ability to participate meaningfully in family court processes that are scheduled to take place outside their home community in the base court"; ${ }^{87}$ and prior to court days ensure that interpretation services are available.

From these issues and recommendations, it should be clear that there are significant access to justice issues for First Nations people living in Northern Ontario on remote reserves. The level of barriers for basic services offered to other Ontarians by Legal Aid of Ontario and the Ministry of the Attorney General are notably difficult to overcome for First Nations without regular interactions with court systems and legal proceedings or access to legal advocates to maneuver through those barriers. The consequences for not having legal advice or the ability to timely file family law documents can be devastating in court processes. The system of flyin courts sets First Nation people up for failure due to the lack of access, lack of regular interaction, and diminished ability to allow relationships to build and engage communities in understanding legal processes.

The author witnessed this firsthand on a visit to a fly-in court held at the Pickle Lake Community Centre on 25 August 2017. The community centre building was small and dilapidated located beside a liquor store. ${ }^{88}$ In speaking with Band Councillor Tom Wassaykeesic from the nearby Mishkeegogamang Ojibway Nation, they had requested for years to move the fly-in court to the reserve approximately $30 \mathrm{~km}$ from the airport where the majority of those involved in court proceedings lived. ${ }^{89}$ The presiding judges for the fly-in court over the years had consistently refused the request and most recently the regional senior judge for the Thunder Bay district had as well. ${ }^{90}$ This was in spite of the fact that the First Nation had a new state of the art community centre with room for courtrooms, separate meeting rooms to protect witnesses and allow privacy for client-lawyer meetings, and was located across from a nursing station and next door to a Nishnawbe Aski Police Service station..$^{91}$ He stressed that it was a hardship for the First Nations people to come to court in Pickle Lake as there was no public transportation and, in the wintertime, it was especially brutal. The reason given for the refusal to have court at the reserve community centre was given as "a concern for safety" which he viewed as unfounded and "an exaggerated fear" and based on a racist view of the First Nation..$^{92}$ He strongly spoke of the inherent right to selfgovernment for his First Nation and that it was a goal of his community to "have our own court system, with our own laws and our own justice."93

Ibid.

Ibid at 12 .

In the author's opinion, holding court proceedings next door to a liquor store is setting up stressed and emotional Aboriginal people to fail as the temptation to engage in drinking for vulnerable persons is greatest during times of stress.

Interview of Tom Wassaykeesic (25 August 2017).

Ibid.

Ibid.

Ibid.

Ibid. 


\section{Attempts at Stemming the Tide of Aboriginal Children in CARE}

The first five of the TRC Calls to Action focus on child welfare and improving the intercultural interactions to stem the tide of removal of Aboriginal children from their homes and communities. ${ }^{94}$ As noted in the beginning legacy section of the Calls to Action, the removal of children from their homes through contemporary processes is akin to the mass removal of children during the Indian residential school system from the 1831 establishment of the Mohawk Indian Residential School in Brantford, Ontario to the closure in 1996 of the last school, the Gordon Indian Residential School in Punnichy, Saskatchewan. ${ }^{95}$ An entire volume of the Truth and Reconciliation Commission's Final Report is dedicated to child welfare which can be summarized as follows: "[t]he child welfare system is the residential school system of our day." 96

Provincial courts and child welfare agencies have been heavily involved in the apprehension and removal of Aboriginal children from their homes and families. From the residential school era of mandatory attendance for Aboriginal children to the current government and agency removal of children, the ongoing disruption of Aboriginal families is occurring in Canada backed by legal systems. ${ }^{97}$ The very first Call to Action targets all levels of Canadian and Aboriginal government to commit to decreasing the number of Aboriginal children in care and sets forth five action steps for governments to take. ${ }^{98}$ The immediately subsequent Calls to Action push governments to provide annual reporting on the number of Aboriginal children in care compared to non-Aboriginal children ${ }^{99}$ and the implementation of Jordan's Principle ${ }^{100}$ to provide proper payments for services to Aboriginal children without engaging in jurisdictional disputes between the federal and provincial governments. In the next Call to Action, passage of legislation is called for to provide national standards for Aboriginal child apprehension and custody cases that includes Aboriginal government-run child welfare agencies, judges, and agencies taking the legacy of Indian residential schools into account, and that placements of Aboriginal children, whether temporary or permanent, be in culturally appropriate homes or environments as an immediate priority. ${ }^{101}$ The legacy section concludes with a Call to Action for Canadian and Aboriginal governments "to develop culturally appropriate parenting programs for Aboriginal families."102

TRC, Vol 6, supra note 5 at Recommendations 1-5.

See The Legacy of Hope Foundation, "Reclaiming History: The Residential School System in Canada," online: $<$ wherearethechildren.ca/en/timeline/research/>.

TRC, Vol 5, supra note 9 at 4.

See Robert Matas, "What the Numbers Say," The Globe and Mail (19 June 2009), online: <https:// www.theglobeandmail.com/news/national/what-the-numbers-say/article4277082/> ("Aboriginal children are over-represented at all stages of government involvement in child protection").

TRC, Vol 6, supra note 5 at Recommendation 1.

Ibid at Recommendation 2.

Ibid at Recommendation 3. Jordan's Principle is more fully explained as the principle that the first government agency contacted for child services must pay for it while it pursues reimbursement. See TRC, Vol 5, supra note 9 at 25-26.

TRC, Vol 6, ibid at Recommendation 4.

Ibid at Recommendation 5. 


\section{A. The aboriginal Child Welfare HuMAN Rights CRISIS IN CANADA}

These Calls to Action were developed in response to the treatment of Aboriginal children by Canadian government policy. First, children were forcibly abducted to attend Indian residential schools for over a hundred years, then from approximately 1965 to 1984 a government backed policy known as the "Sixties Scoop" occurred. ${ }^{103}$ The "Sixties Scoop" was the policy implemented by provincial child welfare agencies to apprehend thousands of Aboriginal children on reserves and place them in foster care with non-Aboriginal families or in adoptive homes with non-Aboriginal families. In 2017, the Ontario Superior Court of Justice in Brown v. Canada (A.G. $)^{104}$ found in favour of the class action on behalf of Sixties Scoop survivors against the government of Canada. In the judgment, Canada was found to have breached its fiduciary duty and duty of care to the survivors which resulted in both psychological and spiritual harm. The Court summarized the uncontroverted expert evidence as demonstrating that the removed Aboriginal children suffered a loss of identity and profound disorientation impacting their lives and resulting in "psychiatric disorders, substance abuse, unemployment, violence and numerous suicides." 105 After eight years of litigation, the ruling was appealed by Canada and compensation for a settlement was announced for all First Nation and Inuit children removed between 1951 and $1991 .{ }^{106}$ After an outcry that Métis Sixties Scoop survivors were excluded from the settlement, a class action has been filed in Saskatchewan to seek a similar settlement for non-status Indians and Métis survivors. ${ }^{107}$

The removal of Indigenous children is not a thing of the past as apprehension continues to be the primary work of child welfare agencies backed by court systems in Canada. In January 2016, the Canadian Human Rights Tribunal ruled that Aboriginal children on reserves and in the Yukon were denied adequate federal funding for medical services under the First Nations Child and Family Services (FNCFS) Program and often the result was to take children into care where funding was more readily available. ${ }^{108}$ Recent news stories on the flimsy reasons for apprehension of Aboriginal children have become more frequent with reporting on conditions such as poverty, housing shortages, and substance abuse as grounds for agency removals. ${ }^{109}$ Advocates for Aboriginal children have highlighted the need to provide funding and supports for families, rather than for foster care and adoptive

See John Paul Tasker, “Judge Rules in Favour of Indigenous Survivors of Sixties Scoop,” CBC News (24 February 2017), online: <https://www.cbc.ca/news/politics/60s-scoop-ruling-aboriginal-1.3981771>. 2017 ONSC 251.

Ibid at para 7 .

See John Paul Tasker, "Ottawa Announces \$800M Settlement with Indigenous Survivors of Sixties Scoop," CBC News (5 October 2017), online: <www.cbc.ca/news/politics/ottawa-settle-60s-scoopsurvivors-1.4342462>.

See "Métis Sixties Scoop Survivor Sues Federal and Saskatchewan Governments," CBC News (29 January 2018), online: <www.cbc.ca/news/canada/saskatoon/robert-doucette-60s-scoop-lawsuit-1.450 $8618>$.

See First Nations Child and Family Caring Society of Canada v Canada (AG), 2016 CHRT 2 at para 383. See also Cindy Blackstock, "The Complainant: The Canadian Human Rights Case on First Nations Child Welfare" (2016) 62:2 McGill LJ 285 at 324-26 (noting the intransigence of the federal government after the decision as disappointing).

See Angela Sterritt, "Indigenous Kids Largely Apprehended Because of Poverty, Says Former Child Protection Worker," CBC News (21 November 2017), online: <www.cbc.ca/news/canada/britishcolumbia/indigenous-children-largely-apprehended-because-they-dont-have-access-to-basic-resources$1.4412441>$. 
placements. ${ }^{110}$ "In 2016, First Nation, Metis and Inuit youth made up 52 per cent of foster children younger than 14 in Canada, despite representing just eight per cent of that age group, according to Statistics Canada." 111 Further, Indigenous Services Minister Jane Philpott noted in November of 2017 the perverse incentive that child welfare agencies receive greater funding for the number of Aboriginal children in care rather than for providing services to keep the children in their homes. ${ }^{112}$ She also stated that currently in Manitoba 11,000 children are in care and Aboriginal children comprised 10,000 of those children. ${ }^{113}$

\section{B. IMPROPER APPLICATION OF THE "BEST INTERESTS OF THE CHILD" STANDARD BY COURTS}

Canadian courts apply the best interest of the child legal standard to apprehensions and placements of Aboriginal children. ${ }^{114}$ Due to the poverty conditions, underfunding of reserve services, lack of educational opportunities, and social issues experienced by Aboriginal parents, judges applying the best interest of the child legal standard have placed Aboriginal children into non-Aboriginal foster care and adoptive placements. ${ }^{115}$ In the Supreme Court of Canada decision Young v. Young, the roots of the best interests of the child legal standard are traced from the United Kingdom Courts of Chancery employing the parens patriae jurisdiction of the courts to the contemporary legal standard that places the welfare of the child "over any potential rights that parents previously held at common law." judges are, by and large, non-Aboriginal ${ }^{117}$ without sufficient understanding of the realities experienced on reserves when child welfare agencies seek removal and placement of Aboriginal children, nor do they adequately grasp their own biases in assessing the parenting capacity of Aboriginal people or ultimately, the best interests of an Aboriginal child. ${ }^{118}$

$110 \quad$ Ibid

111 Kyle Edwards, "The Stunning Number of First Nations Kids In Foster Care - And the Activists Fighting Back," MacLean's (10 January 2018), online: <www.chatelaine.com/living/first-nationsfighting-foster-care/ $>$.

112 Jorge Barrera, "Indigenous Child Welfare Rates Creating 'Humanitarian Crisis' in Canada, Says Federal Minister," CBC News (2 November 2017), online: <www.cbc.ca/news/indigenous/crisis-philpott-childwelfare-1.4385136>.

113 Ibid.

114 See e.g. Child, Youth and Family Services Act, 2017, SO 2017, c 14, Schedule 1 ("[t]he paramount purpose of this Act is to promote the best interests, protection and well-being of children," s 1(1)).

115 See Stephanie Jansen, “Aboriginal Children and Child Welfare Policies,”LawNow (7 July 2014), online: $<$ www.lawnow.org/aboriginal-children-child-welfare-policies/> ("[t]he 'best interest of the child' legal standard all but guarantees the removal of First Nations children from their traditional homes into Canadian Christian homes").

116 Young $v$ Young, [1993] 4 SCR 3 at 36, L'Heureux-Dubé J dissenting in part.

117 See Andrew Griffith, "Diversity Among Federal and Provincial Judges," Policy Options (4 May 2016), online: <policyoptions.irpp.org/2016/05/04/diversity-among-federal-provincial-judges/> (noting at Figure 3 that Quebec, New Brunswick, Prince Edward Island, Newfoundland, and the North have no Indigenous judges).

118 See Peter Choate \& Gabrielle Lindstrom, "Parenting Capacity Assessment as a Colonial Strategy" (2017) 37:1 Can Fam LQ 41 at 48-49 [footnotes omitted]:

If this intergenerational trauma is not understood and incorporated into assessment methodology, then the client is at immediate disadvantage as the ecological and historical reality of the client is not a mediating element of the data to be considered. The Supreme Court of Canada has addressed this in criminal matters in $R$. v. Gladue by noting the unique circumstances of Aboriginal people. It is our contention that these same unique considerations apply to child intervention assessments. 
For the reasons set forth above, an entirely new paradigm for Aboriginal children is necessary to allow for Aboriginal children to grow up in their home communities surrounded by their families, culture, language, and sense of belonging. Generations of Aboriginal children in Canada have been abducted under governmental authority and subjected to isolation, insecurity, loss of identity, and often abuse. These circumstances amount to a human rights crisis for the continuation of Indigenous peoples in their homelands. The Canadian court systems have enforced this situation and the solution must start with a new legal system governed by Indigenous peoples, as discussed further in Part V.

\section{A Model: DEVELOPMENT AND OPERATION of Tribal COURTS IN THE UNITED STATES}

Both Canada and the US have the common ancestry of governments derived from colonies of Great Britain located in North America. ${ }^{119}$ As the siblings of Father England, these two countries share very similar legal traditions, European norms, and a similar history of colonization of the Indigenous peoples of North America by settler-nations. ${ }^{120}$ Paternalistic views of control over Indigenous life, government, commerce, and social behaviour have been characteristic of these brother governments following in the footsteps of the empire building of the kings of England. ${ }^{121}$ Further, the British Crown continues to have an active and engaged presence in Canadian law, politics, and society. ${ }^{122}$

\section{A. SimiLARITIES TOWARDS INDIGENOUS RELATIONS in Canadian and United States Policy}

Both governments view the Royal Proclamation of 1763 as foundational in defining the relationships with Indigenous nations. Both engaged in treaty-making as an expeditious means of gaining large areas of land for settlement and writing those treaties in the English legal language that often differed from the oral agreements made with Indigenous leaders. ${ }^{123}$ As legal principles for asserting title over Indigenous lands developed, the Canadian courts borrowed from the United States Supreme Court's decision in Johnson v. McIntosh ${ }^{124}$ which

See Nell Jessup Newton, Felix Cohen \& Robert Anderson, eds, Cohen's Handbook of Federal Indian Law, 2012 ed (San Francisco: LexisNexis, 2012), § 1.02[1]-[2] at 12-19 [Cohen's Handbook]. Ibid at $16-17$.

See generally Phillip Buckner, ed, Canada and the British Empire (Oxford: Oxford University Press 2010).

See e.g. $R v$ Badger, [1996] 1 SCR 771 ("the honour of the Crown is always at stake in its dealing with Indian people. Interpretations of treaties and statutory provisions which have an impact upon treaty or aboriginal rights must be approached in a manner which maintains the integrity of the Crown. It is always assumed that the Crown intends to fulfil its promises" at para 41).

See Cohen's Handbook, supra note 119, § 1.03[1] at 26-30; Report of the Royal Commission on Aboriginal Peoples: Looking Forward, Looking Back, vol 1 (Ottawa: Minister of Supply and Services Canada, 1996) at 113-14 [RRCAP, vol 1]:

In the opening stages of British settlement in North America, this collision of interests resulted in warfare and led to the forcible dispossession of Aboriginal nations in Virginia and New England. Many Aboriginal nations allied themselves with the French or retreated before the advance of the British colonists. Over time, however, and to avoid further hostilities, a policy developed whereby lands required for settlement would ordinarily be secured from their Aboriginal owners by formal agreement. Thus, treaties specifically involving land cessions by Aboriginal nations soon became a common feature of the British-Aboriginal relationship.

21 US (8 Wheat) 543 (1823). 
laid out the doctrine of discovery colonization theory. ${ }^{125}$ The similarities continue as the Canadian government set up a system of Indian residential schools that followed the US Carlisle Indian Industrial School model with both forcing mandatory attendance for Indigenous children. ${ }^{126}$ In more contemporary times, both governments engaged in policies of removal of Indigenous children during the 1960s for adoption into non-Indigenous homes on a mass scale. ${ }^{127}$ Furthermore, both governments are pushing to expand oil pipelines and other resource initiatives through Indigenous homelands while there is staunch opposition of Indigenous leaders and citizenry. ${ }^{128}$ These examples demonstrate the common roots of the paternalism experienced by Indigenous peoples in North America from these two British derived settler-nations, Canada and the United States of America.

\section{B. The Oscillation of United States Indian Policy ERaS}

In teaching US federal Indian law, the metaphor of a pendulum is often employed as swinging between two poles, on the one side is support of tribal sovereignty and on the other side is destruction of tribal sovereignty. In the US Indian law policy eras, ${ }^{129}$ the pendulum oscillates between these two policy goals from the inception of the US government. As demonstrated in Figure 1 below, the pendulum begins in the recognition of US and Tribal Nations sovereign-to-sovereign relations during the treaty-making era. The next era is harder to define with both policies' goals being espoused simultaneously with different Tribal Nations. For some, the experience was removal from homelands through US military marches to distant territories. ${ }^{130}$ For others, the treaty language was upheld to secure strong reservation boundaries and recognition of tribal jurisdiction in all matters within those boundaries. The tide again turned with the pendulum swinging firmly to the destruction of the tribal government side with the passage of the General Allotment Act of 1887 to break up the tribal land base ${ }^{131}$ and the full-scale implementation of the assimilation policy. This era is identified by the US governments actions of kidnapping American Indian children to attend government and religious-run boarding schools; implementation of a federal code of laws outlawing Indigenous culture, spiritual practices, and resistance to US policies; and the

Ibid ("[t]his principle was, that discovery gave title to the government by whose subjects, or by whose authority, it was made, against all other European governments, which title might be consummated by possession" at 573). See RRCAP, vol 1, supra note 123 at 309-12.

127 In Canada, the Sixties Scoop occurred between the late 1950s and into the 1980s where Aboriginal children were removed from their homes and families and placed in non-Aboriginal adoptive homes or foster care. See generally Patrick Johnston, Native Children and the Child Welfare System (Ottawa: Canadian Council on Social Development, 1983). For the US, see Angelique EagleWoman \& G William Rice, "American Indian Children and U.S. Indian Policy" (2016) 16 Tribal LJ 1 ("[t]hrough the 1950s to the $1970 \mathrm{~s}$, thousands upon thousands of Indian children were torn from their families by social services personnel and missionaries, generally without the consent of tribal leaders, the Indian community or the families concerned. Most of these children were placed with non-Indian adoptive parents or foster homes" at 18).

128 For recent events in Canada on pipeline issues, see Naomi Klein, "Indigenous Leaders Shut Down Construction on Kinder Morgan's Pipeline," Cision (7 April 2018), online: <https://www.newswire. $\mathrm{ca} /$ news-releases/indigenous-leaders-shut-down-construction-on-kinder-morgans-pipeline679065693.html>. For news on Indigenous peoples from Canada and the US joining forces to voice opposition to oil pipeline development, see "Indigenous Leaders Sign Opposition to Keystone XL in Calgary," CBC News (17 May 2017), online: <www.cbc.ca/news/canada/calgary/transcanada-keystonecalgary-indigenous-1.4119301>. For a more robust discussion of the US Indian policy eras, see Angelique Townsend EagleWoman \& Stacy L Leeds, Mastering American Indian Law (Durham: Carolina Academic Press, 2013) at 8-18.

130 See Cohen's Handbook, supra note 119, §1.03[4][a] at 41-51.

131 General Allotment Act, 25 USC $\$ 331$ (1887). See generally Judith V Royster, "The Legacy of Allotment" (1995) 27:1 Ariz St LJ 1. 
establishment of a special court system, Courts of Indian Offenses to implement the Code of Federal Regulations. ${ }^{132}$

In 1934, the pendulum swung back towards support of tribal sovereignty with the momentous passage of the Indian Reorganization Act. ${ }^{133}$ This federal law recognized Indian self-government and provided for the adoption of tribal constitutions, ${ }^{134}$ creation of federal charters for tribal corporations, ${ }^{135}$ ended the US policy of allotment of tribal lands, ${ }^{136}$ and provided means and funding to restore homelands to Tribal Nations. ${ }^{137}$ As Tribal Nations asserted self-government and became increasingly prosperous, the backlash by states and local non-Indian citizens led to the pendulum returning to the destruction side of tribal government for the Indian government termination era whereby the US Congress removed federal recognition of "approximately 110 tribes and bands in eight states." ${ }^{138}$ Unified tribal leadership and urban Indian organizations responded and voiced opposition to this new US Indian policy which led to the final pendulum swing to where the current policy is: Indian self-determination from the late 1960 s to the present.

\section{FigURE 1: DEPICTING US GOVERNMENT'S OSCILLATION BETWEEN \\ SUPPORT OF TRIBAL SOVEREIGNTY AND DESTRUCTION OF \\ Tribal SOVEREIGNTY IN SETTING GOVERNMENTAL INDIAN POLICY Throughout History}

\begin{tabular}{|l|l|}
\hline \multicolumn{1}{|c|}{ Support of Tribal Sovereignty } & \multicolumn{1}{c|}{ Destruction of Tribal Sovereignty } \\
\hline $\begin{array}{l}\text { Sovereign-to-Sovereign Relations: Treaties } \\
1778 \text { to mid-1800s }\end{array}$ & \\
\hline Reservation Era 1800s & Removal Era 1800s \\
\hline & $\begin{array}{l}\text { Allotment/Assimilation Era } \\
1800 \text { s to early 1900s }\end{array}$ \\
\hline $\begin{array}{l}\text { Indian Self-Government Era } \\
1930 \text { s to 1940s }\end{array}$ & \\
\hline & (Indian Government) Termination Era \\
& 1940 s to 1960s \\
\hline $\begin{array}{l}\text { Indian Self-Determination Era } \\
\text { Late 1960s to present }\end{array}$ & \\
\hline
\end{tabular}

During the present US Indian policy era of Indian self-determination, a host of significant legislation has been passed to ameliorate some of the worst colonial and assimilationist laws and policies inherited from past eras and administrations. First, the Indian Self-Determination and Education Assistance Act of $1975^{139}$ is noteworthy as providing a means for tribal

\footnotetext{
132 See Cohen's Handbook, supra note $119, \S 1.04$ at 75-76.

25 USC \& 5101 (formerly cited as 25 USC \$461).

Ibid, $\S 5123$ (formerly cited as 25 USC $\S 476$ ).

Ibid, § 5124 (formerly cited as 25 USC $\S 477$ ).

Ibid, § 5101 (formerly cited as 25 USC $\$ 461$ ).

Ibid, § 5103 (formerly cited as 25 USC § 463), § 5108 (formerly cited as 25 USC $\S 465$ ), $\S 5110$ (formerly cited as 25 USC $\S 467$ ).

Michael C Walch, "Terminating The Indian Termination Policy" (1983) 35:6 Stan L Rev 1181 at 1186.
} 25 USC $\S 5301$ (formerly cited as 25 USC $\S 450$ ). 
governments to contract with the Bureau of Indian Affairs ${ }^{140}$ to deliver tribally managed educational institutions from elementary to the post-secondary level along with other service programs operated on reservations. ${ }^{141}$ Thus, many tribal governments manage and deliver law enforcement services, child protection services, elderly program and support services, and health and wellness programs among others. ${ }^{142}$ Second, the Indian Child Welfare Act of $1978^{143}$ has had a considerable impact on bringing tribal involvement into safeguarding American Indian children and preserving families. ${ }^{144}$ This will be discussed further below. Through all of these policy swings by the US government, Tribal Nations maintained their inherent tribal sovereignty as the locus of authority for governance and relations with other governments. $^{145}$

\section{Establishment of Tribal Courts in the United States}

In contrast to the situation for First Nations in Canada, the shift in US Indian policy with the Indian Reorganization Act (IRA) of 1934 formally authorized the re-emergence of tribal institutions of self-governance. ${ }^{146}$ With the passage of the IRA, a majority of Tribal Nations adopted tribal constitutions that authorized formal operation of tribal court systems. Today, there are over 330 formal tribal courts in operation in tribal communities in the US. ${ }^{147}$ If a Tribal Nation has not established a tribal court, then either the elected Tribal Council serves as the judicial forum or the default Federal Court of Indian Offenses (also called CFR courts) may provide judicial services. ${ }^{148}$ Also, smaller Tribal Nations may seek resolution of disputes in culturally-affiliated courts of larger Tribal Nations. The jurisdiction of the tribal courts has been limited by federal legislation and US Supreme Court decisions on the bounds of civil ${ }^{149}$ and criminal jurisdiction over non-Indians. ${ }^{150}$ Tribal courts have full jurisdiction over tribal members within their territorial jurisdiction and subject matter jurisdiction on certain activities of others. ${ }^{151}$ While there are efforts to expand and broaden the jurisdiction of tribal courts, these systems serve as a model for other Indigenous governments world-wide.

See US Department of the Interior, "History of BIA," online: <https://www.bia.gov/bia>:

Since its inception in 1824, the Bureau of Indian Affairs has been both a witness to and a principal player in the relationship between the Federal Government and Indian tribes and Alaska Native villages. The BIA has changed dramatically over the past 185 years, evolving as Federal policies designed to subjugate and assimilate American Indians and Alaska Natives have changed to policies that promote Indian self-determination.

On the Canada side, the historic federal agency, Indigenous and Northern Affairs (INAC) was restructured in August 2017 by Prime Minister Justin Trudeau into two new agencies: (1) Indigenous Services Canada, and (2) Crown-Indigenous Relations and Northern Affairs Canada. See Government of Canada, "Crown-Indigenous Relations and Northern Affairs Canada," online: < https://www.canada. $\mathrm{ca} /$ en/crown-indigenous-relations-northern-affairs.html? ga $=2.40212450 .1332743397 .1536085321$ $1001472106.1536085321>$.

See Cohen's Handbook, supra note 119, § 22.02[1] at 1386-88.

Ibid.

25 USC $\$ \S 1901-23$.

See Cohen's Handbook, supra note 119, § 11.01 at 830 .

Ibid, $\$ 4.01[1][\mathrm{a}]$ at $206-207$.

Ibid, § 1.05 at $83-84$.

For a listing of the 332 tribal courts, see Tribal Court Clearinghouse, "Tribal Courts," online: $<$ www.tribal-institute.org/lists/justice.htm $>$.

See Cohen's Handbook, supra note 119, § 4.04[3][c][iv][B]-[C] at 266-67.

See Strate v A-1 Contractors, 520 US 438 (1997) (holding that federal review is available to non-Indian civil defendants on the question of tribal jurisdiction over the non-Indian's conduct); see also Cohen's Handbook, ibid, § 7.02[a][1] at 599-600.

See Oliphant v Suquamish Indian Tribe, 435 US 191 (1978) (holding that tribal courts lacked criminal jurisdiction over non-Indian offenders within the tribal territory); see also Cohen's Handbook, ibid, $\$ 9.04$ at $765-67$.

Ibid, $\S 7.02[a][1]$ at 599-601. 
Tribal courts are established from the authority of tribal governments and operate according to tribal laws. A tribal government may authorize the judicial branch through inclusion in the tribal constitution or through tribal statute. ${ }^{152}$ The governing documents for tribal courts will include the jurisdiction of the trial level court and the process for appellate jurisdiction. Some Tribal Nations join appellate circuits such as the Northern Plains Intertribal Court of Appeals ${ }^{153}$ or the Southwest Intertribal Court of Appeals. ${ }^{154}$ Others may appoint an appellate panel of three justices as necessary. ${ }^{155} \mathrm{With}$ the majority of tribal courts formed through the adoption of boilerplate constitutions authorized under the 1934 IRA, the courts are now reaching a stage of maturity after operating formally for over eighty years. In support of tribal court systems, there are several national organizations that provide training, best practices, and opportunities for networking amongst tribal judges and tribal court personnel. ${ }^{156}$

Tribal court judges are both Indigenous and non-Indigenous with a requirement of understanding the local tribal law and federal Indian law. ${ }^{157}$ Some courts allow for tribal advocates to represent parties and the advocates may be respected community members or other laypersons. Native lawyers and law professors are often called to serve as pro tempore judges and compose appellate judicial panels, along with non-Natives practicing or teaching in the field of federal Indian law. ${ }^{158}$ This may vary between tribal courts, but all seek respectful and respected judges to serve and uphold tribal law.

The Navajo Nation judicial system ${ }^{159}$ has been a model within the US and internationally as operating based on Navajo culture and principles, particularly in its specialized Peacemaker Court. ${ }^{160}$ "The Navajo dispute resolution system called peacemaking brings parties and communities together on amicable terms, costs a fraction of adversarial court litigation, does not cast blame on wrongdoers, and identifies and treats the underlying cause of the problem." "161 To serve as a judge for the Navajo Nation, the applicant must be fluent in the Navajo language and all lawyers must take the Navajo Nation bar exam to be admitted for court appearances. ${ }^{162}$ Navajo law and stories are often employed in judicial opinions to explain legal principles and the basis for decisions and orders in the courts. ${ }^{163}$

Ibid, § 4.04[3][c][iv][B] at 265 .

See NPICA, online: <npica-com.doodlekit.com/home/index>.

See American Indian Law Center, "Southwest Intertribal Court of Appeals," online: < ailcinc.org/SWITCA.htm>.

See Cohen's Handbook, supra note 119, § 4.04[3][c][iv][C] at 267.

See National American Indian Court Judges Association (NAICJA), “About Us," online: $<$ https:// naicja.wildapricot.org/>; Tribal Law and Policy Institute, online: <www.home.tlpi.org/>; The National Judicial College, "Tribal Center," online: <www.judges.org/ntjc/news/>.

See Cohen's Handbook, supra note 119, § 4.04[3][c][iv][C] at 267-68.

See generally Frank Pommersheim, Tribal Justice: Twenty-Five Years as a Tribal Appellate Justice (Durham: Carolina Academic Press, 2016).

See the Judicial Branch of the Navajo Nation, online: <www.navajocourts.org/>.

See Howard L Brown, “The Navajo Nation's Peacemaker Division: An Integrated Community-Based Dispute Resolution Forum" (2001) 24:2 Am Indian L Rev 297 at 308.

See Raymond D Austin, Navajo Courts and Navajo Common Law: A Tradition of Tribal SelfGovernance (Minneapolis: University of Minnesota Press, 2009) at 202.

See Raymond D Austin, "American Indian Customary Law in the Modern Courts of American Indian Nations" (2011) 11:2 Wyo L Rev 351 at 360.

Ibid at 361-62. 
Tribal courts often follow a hierarchy of law based upon: (1) prior decisions of the same court based on the local tribal statutes and customary law principles, (2) the tribal decisions of other Tribal courts, (3) relevant federal court decisions, and (4) relevant state court decisions. ${ }^{164}$ This hierarchy is flexible and may be followed in a different order depending on the subject matter before the court. For example, some tribal governments have adopted the Uniform Commercial Code (UCC) which is heavily relied upon by state courts. ${ }^{165}$ Relevant state court decisions on sections of the UCC may be primary sources for judicial decisions in those instances. There have also been uniform codes proposed for adoption by tribal governments, particularly in the area of commercial dealings. ${ }^{166}$ Tribal courts employ court staff from the local community and usually have a judicial board to govern court policies. As part of tribal governance, tribal courts are key to ensuring consistent laws are enforced for economic development, such as with business licensing and commercial transactions.

Tribal governments must balance the competing interests of applying tribal legal principles and evolution of an Indigenous jurisprudence with expectations of those within the jurisdiction of the tribal court system who seek written statutes and precedential judicial decisions to prepare their advocacy. The US Supreme Court has issued several decisions curtailing the jurisdiction of tribal courts when non-Indians are parties to a tribal court action by focusing on the types of activities which give rise to such jurisdiction. ${ }^{167}$ These decisions seem to signal some hesitation of fully embracing tribal courts as within the fabric of the national judiciary. As Justice Sandra Day O'Connor noted, “[t]he judicial systems of the three sovereigns - the Indian tribes, the Federal government, and the States - have much to teach one another." ${ }^{\prime 68}$ Across the country, there are numerous tribal-state court forums that engage in collaborative efforts to better serve all community members who frequently interact with each other. ${ }^{169}$

\section{Criminal Jurisdiction in Tribal Courts}

As this article focuses on tribal courts, the fundamental premises for criminal law jurisdiction in the tribal territory will be discussed. Criminal law and jurisdiction has often been referred to as a maze due to the intricacies of overlapping federal laws and at times the application by federal authorities of state criminal offenses within tribal territories. ${ }^{170}$ Tribal courts share concurrent jurisdiction with federal authorities in tribal territories for serious or felony offenses committed by Indians, whether tribal members or members of other Tribes. ${ }^{171}$

See e.g. Matthew LM Fletcher, "Rethinking Customary Law in Tribal Court Jurisprudence" (2007) 13:1 Mich J Race \& L 57 at 61-64.

See John F Petoskey, "Doing Business with Michigan Indian Tribes" (1997) 76:5 Mich Bar J 440 at 443. See Fred H Miller \& Duchess Bartmess, "Uniform Laws: Possible Useful Tribal Legislation" (2000) 36:2 Tulsa LJ 305 at 313-14.

For a full discussion, see Sarah Krakoff, "Tribal Civil Judicial Jurisdiction Over Nonmembers: A Practical Guide for Judges" (2010) 81:4 U’ Colo L Rev 1187.

Hon Sandra Day O'Connor, "Lessons from the Third Sovereign: Indian Tribal Courts" (1997) 33:1 Tulsa LJ 1 at 5 .

See Aaron F Arnold, Sarah Cumbie Reckess \& Robert V Wolf, "State and Tribal Courts: Strategies for Bridging the Divide" (2012) 47:3 Gonz L Rev 801 at 821-22; State of Idaho Judicial Branch, "Tribal State Court Forum," online: <https://www.isc.idaho.gov/tribal-state/tribalcourt>.

See James D Diamond, "Practicing Indian Law in Federal, State, and Tribal Criminal Courts: An Update About Recent Expansion of Criminal Jurisdiction Over Non-Indians" (2018) 32:4 Criminal Justice 8 at 9.

See Cohen's Handbook, supra note 119, § 9.04 at 765-69. 
For misdemeanor or lower offenses, tribal courts are the primary jurisdiction when offenses are committed by Indians, whether tribal members or members of other Tribes. ${ }^{172}$

In Oliphant v. Suquamish Indian Tribe, ${ }^{173}$ the US Supreme Court set a barrier for tribal courts to exercise criminal jurisdiction over non-Indians. Thus, depending on the type of crime committed by non-Indians within reservations, federal or state prosecution is applicable with one exception. In 2013, the US Congress passed the Violence Against Women Act (VAWA) and authorized tribal court jurisdiction over non-Indians in domestic violence cases. ${ }^{174}$ Due to the overwhelming reports of violence against Indigenous women, ${ }^{175}$ the US Congress re-opened the door for local tribal control of domestic violence situations where non-Indians were perpetrating crimes within tribal territories. ${ }^{176}$ Tribal governments must enact conforming law to exercise jurisdiction over domestic violence offenses committed by non-Indians against Indians and tribal protection orders have full faith and credit in other jurisdictions. ${ }^{177}$ This is criminal law jurisdiction in a nutshell for tribal court systems.

In terms of maintaining law and order in tribal communities, tribal courts play a vital role in ensuring consequences for offenders as well as suitable rehabilitative measures through restorative justice processes in many communities. In the 1993 Indian Tribal Justice Act, the US Congress stated that "tribal justice systems are an essential part of tribal governments and serve as important forums for ensuring public health and safety and the political integrity of tribal governments." 178 Further, "traditional tribal justice practices are essential to the maintenance of the culture and identity of Indian tribes." 179

Many tribal courts have developed specialized court sessions that incorporate restorative justice practices. These specialized courts are often called "Healing to Wellness Courts" or "Wellness Courts" and are a step beyond drug courts. ${ }^{180}$ The integration of tribal spiritual practices and compassion for those dealing with addictions, depression and other disorders make these forums important components of healthy tribal communities. ${ }^{181}$

In the twenty-first century, the struggles and terrors facing indigenous peoples - individually and collectively - are as much internal as they are external. In this new millennium citizens of indigenous nations must work together to develop strong, cohesive, and cooperative communities and build solid frames and forms of government. Sadly, conflict and crime caused by alcoholism and drug abuse complicate this struggle. Substance-related offenses and misconduct that interfere with community peace present difficult challenges to all jurisdictions. Costly to adjudicate, it is difficult to provide the balance of treatment and supervision that

Indian Civil Rights Act, 25 USC $\S 1302$ (a) [ICRA] (providing the sentencing authority of tribal courts based on federal law).

Supra note 150.

See ICRA, supra note $172, \S 1304$.

See e.g. Amnesty International, Maze of Injustice: The Failure to Protect Indigenous Women From Sexual Violence in the USA (New York: Amnesty International, 2007).

See Jessica Greer Griffith, "Too Many Gaps, Too Many Fallen Victims: Protecting American Indian Women From Violence on Tribal Lands" (2015) 36:3 U Pa J Intl L 785 at 807-13.

ICRA, supra note 172, § 1304(a)(4). See also US Department of Justice, "Violence Against Women Act (VAWA) Reauthorization 2013," online: $<$ https://www.justice.gov/ tribal/violence-against-women-actvawa-reauthorization-2013-0>

ICRA, ibid, § 3601(5).

Ibid, § 3601(7).

See Joseph Thomas Flies-Away \& Carrie E Garrow, "Healing to Wellness Courts: Therapeutic Jurisprudence +" [2013] Michigan State L Rev 403 at 409-10.

Ibid at 438 . 
offenders and addicts need in order to alter and mend attitudes, minds, and hearts. Fortunately, healing to wellness courts are assisting nations in this task and battle by defending and promoting peace and spawning spiritual revolutions for positive and prosperous change. ${ }^{182}$

Thus, tribal courts are in a position to further community wellness through assisting those charged with crimes by application of restorative principles that are based on traditional tribal values. With the many mental, physical, emotional, and spiritual issues impacting American Indians, these courts represent a return to traditional teachings on bringing those who are struggling into peaceful relations. ${ }^{183}$

\section{E. The INDIAN CHILD WeLFARE ACT OF 1978 AND THE ROLE OF TRIBAL COURTS}

During the 1950s through the 1970s, tribal communities seemed to be under siege by state governmental social workers removing children from their homes and families and asserting a basis of neglect due to poverty and misunderstanding of Indian cultural practices in childrearing. ${ }^{184}$ During this time period, a majority of American Indian families lived in poverty brought on by federal Indian policies spanning the last century. ${ }^{185}$ Tribal leaders across the country testified before the US Congress requesting a federal law to stop the harm of losing generations of children by state actors breaking up Indian families. ${ }^{186}$ In the US Congressional House Report to accompany the bill, the situation was described: " $[\mathrm{t}] \mathrm{he}$ wholesale separation of Indian children from their families is perhaps the most tragic and destructive aspect of American Indian life today." 187 The Report cited to surveys conducted by the Association of American Indian Affairs finding that in 1969 and in 1974 about 25 to 35 percent of all American Indian children had been removed from their homes and placed in largely non-Indian foster care or adoptive homes or institutions. ${ }^{188}$

In response, the Indian Child Welfare Act ${ }^{189}$ (ICWA) was passed to provide uniform standards for state courts to follow when holding "proceedings for termination of parental

Ibid at 447-48 [footnotes omitted].

For more information, see "Tribal Healing to Wellness Courts," online: <www.wellnesscourts.org/>. See Amanda B Westphal, "An Argument in Favor of Abrogating the Use of the Best Interests of the Child Standard to Circumvent the Jurisdictional Provisions of the Indian Child Welfare Act in South Dakota" (2003) 49:1 SDL Rev 107 at 111 [footnotes omitted]:

Indian children were and are often removed by non-tribal governmental officials who have no means to intelligently evaluate the social and cultural premises underlying Native American childrearing and home life. The Native American culture values relationships and child rearing by those outside of the nuclear family.

See Angelique EagleWoman, "Tribal Nations and Tribalist Economics: The Historical and Contemporary Impacts of Intergenerational Material Poverty and Cultural Wealth Within the United States" (2010) 49:3 Washburn LJ 805 at 815-19.

See Cohen's Handbook, supra note 119, § 11.01[2] at 831-33.

US, House of Representatives Committee on Interior and Insular Affairs, Establishing Standards for the Placement of Indian Children in Foster or Adoptive Homes, To Prevent the Breakup of Indian Families and for Other Purposes (HR Rep No 1386) (Washington, DC: US Government Printing Office, 1978) at 9, online: <https://www.narf.org/nill/documents/icwa/federal/lh/hr1386.pdf>. Ibid.

ICRA, supra note 172 , $\S ~ 1901-23$. See also $\S 1902$ Congressional declaration of policy:

The Congress hereby declares that it is the policy of this Nation to protect the best interests of Indian children and to promote the stability and security of Indian tribes and families by the establishment of minimum Federal standards for the removal of Indian children from their families and the placement of such children in foster or adoptive homes which will reflect the unique values of Indian culture, and by providing for assistance to Indian tribes in the operation of child and family service programs. 
rights, adoptions, and foster care placement involving Indian children." ${ }^{\prime 190}$ In the preamble to the statute, the US Congress noted "that there is no resource that is more vital to the continued existence and integrity of Indian tribes than their children and that the United States has a direct interest, as trustee, in protecting Indian children who are members of or are eligible for membership in an Indian tribe." 191 A key feature of the ICWA is recognition that the Tribal Nation has an interest in its children and that interest is as protected as the interests of parents and caregivers.

Throughout the law, standards of proof are set at high-levels to halt arbitrary actions leading to child removal. For example, state social workers must prove that "active efforts have been made to provide remedial services and rehabilitative programs designed to prevent the breakup of the Indian family and that these efforts have proved unsuccessful"192 prior to seeking placement of the child outside of the home. ${ }^{193}$

The active efforts standard is at a higher level than the commonly applied reasonable efforts standard. A second example is in the proof necessary to place a child in foster care. The ICWA requires "clear and convincing evidence" that if the child remains in the home, serious emotional or physical harm will result and therefore, foster care placement is necessary. ${ }^{194}$ Further, in order to terminate parental rights under the ICWA, the evidence must demonstrate "beyond a reasonable doubt, including testimony of qualified expert witnesses, that the continued custody of the child by the parent or Indian custodian is likely to result in serious emotional or physical damage to the child." ${ }^{\prime 195}$ Proof beyond a reasonable doubt is typically a criminal law standard, but has been incorporated into the ICWA to protect parental rights to ensure such rights are not arbitrarily terminated. All of these examples are the safeguards built into the law to curb the state action of breaking up Indian families due to poverty conditions or biases towards Indian family practices. ${ }^{196}$

\section{EXCLUSIVE JURISDICTION OVER CHILD PROCEEDINGS IN TRIBAL COURTS}

Under the ICWA, tribal courts have exclusive jurisdiction over proceedings involving an American Indian child who is a resident of his or her home reservation or is domiciled on his or her home reservation. ${ }^{197}$ Further, if an Indian child is a ward of the tribal court, then exclusive jurisdiction over proceedings involving that child will be retained by the court. ${ }^{198}$ These provisions oust state or federal jurisdiction, except when federal law has vested

See Kelsey Vujnich, “A Brief Overview of the Indian Child Welfare Act, State Court Responses, and Actions Taken in the Past Decade to Improve Implementation Outcomes" (2013) 26:1 J American Academy Matrimonial Lawyers 183 at 186-87. 
jurisdiction in the state ${ }^{199}$ whereby concurrent jurisdiction will exist for the tribal court. ${ }^{200}$ Thus, the authority and operation of tribal courts are essential to carry out the functions of the ICWA and allow Tribal Nations to oversee proper outcomes for children in need of care.

\section{Transfer of Proceedings From State to Tribal Court}

The ICWA is a truly unique federal law as it provides for the transfer of a proceeding involving an Indian child from a state court to a tribal court. ${ }^{201}$ This will apply when an Indian child is domiciled off of his or her home reservation and a state court proceeding is commenced involving the placement of the child outside of the parental home. The transfer provisions are as follows:

\footnotetext{
In any State court proceeding for the foster care placement of, or termination of parental rights to, an Indian child not domiciled or residing within the reservation of the Indian child's tribe, the court, in the absence of good cause to the contrary, shall transfer such proceeding to the jurisdiction of the tribe, absent objection by either parent, upon the petition of either parent or the Indian custodian or the Indian child's tribe: Provided, [t]hat such transfer shall be subject to declination by the tribal court of such tribe. ${ }^{202}$
}

State courts must follow notice provisions under the ICWA to allow the child's parents, caregiver, and Tribal Nation the ability to timely intervene ${ }^{203}$ and participate in the proceeding. ${ }^{204}$ Upon receiving notice, the tribal representative, parent(s), or caregiver can request the transfer of the action to the tribal court. There is a provision to deny transfer if either parent objects to the transfer, the tribal court declines the transfer, or if "good cause" exists. The 2016 Bureau of Indian Affairs Guidelines are interpretative material to assist in the implementation of the ICWA and provide that "good cause" should be construed narrowly and applied in a forum non conveniens ${ }^{205}$ manner, rather than to frustrate the purposes of the law. ${ }^{206}$

During the termination era of US Indian policy, the US Congress passed a statute providing concurrent state jurisdiction on certain reservations in certain states, known as Public Law 280 jurisdiction. This served as a delegation of federal authority to state authority. Tribal authority remained concurrent preand post-delegation for those tribal governments subject to Public Law 280. See Cohen's Handbook, supra note $119, \S 6.04[3][\mathrm{c}]$ at 555-61. Public Law 280 was codified as 18 USC § 1162; 25 USC $\S \S$ $1321-26 ; 28$ USC $\$ 1360$. ICRA, supra note $172, \S 1911(\mathrm{a})$.

See Cohen's Handbook, supra note $119, \S 11.03$ at 840 .

ICRA, supra note $172, \S 1911(\mathrm{~b})$.

Ibid, § 1911(c): "[i]n any State court proceeding for the foster care placement of, or termination of parental rights to, an Indian child, the Indian custodian of the child and the Indian child's tribe shall have a right to intervene at any point in the proceeding."

$204 \quad$ Ibid, § 1912.

205 Merriam Webster Online Dictionary provides the legal definition of forum non conveniens as "a doctrine allowing a court with jurisdiction over a case to dismiss it because the convenience of the parties and the interest of justice would be better served if the case were brought in a court having proper jurisdiction in another venue," online: <https://www.merriam-webster.com/legal/forum\%20non $\% 20$ conveniens>.

206 US, Bureau of Indian Affairs, Guidelines for Implementing the Indian Child Welfare Act (2016) at 48-49. 


\section{Placement PREFERENCES FOR AMERICAN INDIAN CHILDREN UNDER THE INDIAN CHILD WELFARE ACT}

At the heart of the ICWA are the placement preferences that instruct judicial decisionmakers on where an Indian child in need of care will reside and seek shelter from a family crisis. For foster care placement, the order of preference is as follows:

In any foster care or preadoptive placement, a preference shall be given, in the absence of good cause to the contrary, to a placement with-

(i) a member of the Indian child's extended family;

(ii) a foster home licensed, approved, or specified by the Indian child's tribe;

(iii) an Indian foster home licensed or approved by an authorized non-Indian licensing authority; or

(iv) an institution for children approved by an Indian tribe or operated by an Indian organization which has a program suitable to meet the Indian child's needs. ${ }^{207}$

Upon tribal resolution filed with the state court, the order of the preference placements above may be modified. ${ }^{208}$ Preferences by a child or parent may also be considered in the foster care placement determination. ${ }^{209}$ When a child is to be adopted, the ICWA provides the following placement preferences: "(1) a member of the child's extended family; (2) other members of the Indian child's tribe; or (3) other Indian families." ${ }^{210}$ These placement preferences for foster care and adoption are aligned with the remedial purposes of the ICWA set forth in the law's preamble: to address "that the States, exercising their recognized jurisdiction over Indian child custody proceedings through administrative and judicial bodies, have often failed to recognize the essential tribal relations of Indian people and the cultural and social standards prevailing in Indian communities and families."211

As this section demonstrates, with the establishment of tribal court systems in the 1930s, the tribal courts were available to receive jurisdiction over child proceedings during the crisis of removal that occurred in the 1950s to 1970s. The operation of tribal court systems was fundamental to protecting American Indian children and still is today. There continue to be high profile negative cases involving the $I C W A^{212}$ and anti-tribal interests that call for the law's repeal, but the tribal judiciary and tribal governments are able to continue with the daily work of healing Indian families and protecting Indian children. ${ }^{213}$

ICRA, supra note $172, \S 1915$ (b)

Ibid, $\S 1915(\mathrm{c})$.

Ibid.

Ibid, $\S 1915$ (a).

Ibid, \& 1901(5).

See e.g. Bob Unruh, "3 Attorneys General Sue Feds Over Race-Based Adoption Law," WND (6 May 2018), online: <www.wnd.com/2018/05/3-attorneys-general-sue-feds-over-race-based-adoption-law/>; Ruth Hopkins, "How Foster Care Has Stripped Native American Children of Their Own Cultures," TeenVogue (22 May 2018), online: < https://www.teenvogue.com/story/foster-care-has-failed-nativeamerican-youth>.

See "California News: Attorney General Becerra Leads Bipartisan Coalition of Attorneys General to Protect Native American Children," STL News (26 May 2018), online: <https://www.stl.news/ california-news-attorney-general-becerra-leads-bipartisan-coalition-attorneys-general-protect-nativeamerican-children/128106/>. 


\section{Establishing a SYSTEM OF INDIGENOUS COMMUNITY COURTS}

From the discussion above, the role of court systems in applying community-focused justice and decision-making cannot be overstated. As First Nations in Canada grapple with the overincarceration of their members and the removal of their children from their homes, one solid path forward is through the establishment of a system of Indigenous community courts. The term "Indigenous community courts" (ICCs) is used as provincial courts have been applying the label "First Nation Courts" and "Indigenous Peoples Court" 214 to their restorative justice based sentencing forums and this is distinguished from what is being proposed here.

This proposal is for fully functioning courts within First Nation reserves and communities that operate based on First Nation legal codes, legal principles, customary law, and regulations under the authority of First Nations' governments. These proposed courts may share similar characteristics to the model discussed above for US Tribal Nations in that they could be established through First Nations means, either constitutional enactments or statutes. Within the UNDRIP, article 34 firmly advances the grounds of this proposal:

Indigenous peoples have the right to promote, develop and maintain their institutional structures and their distinctive customs, spirituality, traditions, procedures, practices and, in the cases where they exist, juridical systems or customs, in accordance with international human rights standards. ${ }^{215}$

There should be no question that all First Nations in the Americas practiced dispute resolution with customary practices to restore balance to individuals, situations, and communities. ${ }^{216}$ Under the Canadian Constitution Act, 1982, section 35(1) provides: "[ $\left.\mathrm{t}\right] \mathrm{he}$ existing aboriginal and treaty rights of the aboriginal peoples of Canada are hereby recognized and affirmed." ${ }^{217}$ For First Nations in Canada, community courts would be a return to an area of governance previously enjoyed prior to colonization and should be recognized under international Indigenous legal principles and the government of Canada. ${ }^{218}$ Further, the TRC Call to Action 42 provides for recognition of Indigenous justice systems and conformity with the UNDRIP. ${ }^{219}$

See Part II.C, above, for examples.

UNDRIP, supra note 7 , art 34 .

See generally John Borrows, Canada's Indigenous Constitution (Toronto: University of Toronto Press 2010); Law Commission of Canada, ed, Indigenous Legal Traditions (Vancouver: UBC Press, 2007). See also Wapshkaa Ma'iingan (Aaron Mills), “Aki, Anishinaabek, Kaye Tahsh Crown” (2010) 9:1 Indigenous LJ 107 at 142-43.

Supra note 4, s 35(1).

See Kirsten Manley-Casimir, "Incommensurable Legal Cultures: Indigenous Legal Traditions and the Colonial Narrative" (2012) 30:2 Windsor YB Access Just 137 at 142-43 [footnotes omitted]

Within what is now Canada, there are many examples of jurisgenerative Indigenous communities who created legal systems that pre-existed the non-Indigenous legal system. In the Haudenosaunee Nation, for example, a complex legal system existed that set out principles of government decision-making, consensus, veto powers, and proportional representation. Similarly, the Plains Blackfoot and Cree, had highly developed cultural and legal concepts that structured their understanding that the land could not be privately owned but was to be shared with all creation. Just as the Haudensaunee and Plains First Nations developed systems of law, so other Indigenous peoples developed legal systems to govern their communities. 


\section{A. Proposed Organization AND JURisdiction FOR INDIGENOUS COMMUNITY COURTS}

One of the initial questions when proposing new legal structures such as a court system is: how it should be organized? This proposal is accompanied with suggestions as it is ultimately the authority and responsibility of First Nations to structure contemporary juridical systems based on their own knowledge and expertise. First Nations have ancient confederacies and internal structures based on clans that may inform the location and jurisdiction of specific courts within a larger system. ${ }^{220}$ One suggestion would be to determine the natural physical hub for a group of First Nations as the location of an ICC. For example, in the remote Northern Ontario communities, an ICC located on a reserve that is accessible to others living on reserves in the vicinity would be ideal due to the travel necessary to access court services. ${ }^{221}$

To closely follow the US Tribal Court model, every First Nation government may choose to establish an independent community court and join an intertribal appellate court for efficiency and cost savings. ${ }^{222}$ Taking into consideration the estimated number of criminal and civil cases within single communities and determining accessibility to a chosen court location would be important at the planning stage. The vision would be the realization of community courts throughout First Nation reserves in Canada with the primary authority to hear cases involving First Nation peoples.

The jurisdiction for the ICC would be paramount in establishing the ultimate impact on justice for First Nation peoples. The twin issues of criminal jurisdiction and child welfare for First Nation peoples should be the starting point for setting jurisdiction in these communitybased courts. ${ }^{223}$ Referring to the US tribal court model, criminal jurisdiction should at a minimum extend over alleged offenders within the reserve territorial boundaries and include all Aboriginal peoples within a court's reach. The issue of whether criminal jurisdiction should extend over non-Aboriginal alleged offenders would depend on First Nation governmental officials' consideration of what amount of resources they would choose to devote to rehabilitating non-Aboriginal people through their judicial system(s).

Jurisdiction in civil matters may be more expansive, including any activity that is deemed to impact the First Nation society or territory. Common areas of civil jurisdiction would presumptively be included, such as family law, contracts, torts, commercial law, municipal law, human rights, probate, trusts, guardianships, and other societal areas. With ICCs in operation, mechanisms for transferring child welfare cases from provincial courts to ICCs would be possible, as is the current practice under the ICWA in the United States for the transfer of proceedings involving American Indian children from state courts to tribal courts. $^{224}$

For a discussion on the Great Law within the Iroquois Confederacy, see Mark D Walters, "The Morality of Aboriginal Law" (2006) 31:2 Queen's LJ 470 at 486-87.

See Part II.D, above, on the issues with the current provincial fly-in courts.

See Part IV, above, on the organization of US tribal courts and appellate forums.

See Parts II-III, above, for a discussion on criminal law and child welfare issues for First Nations in Canada.

See Part IV.C, above, for a discussion on the establishment of US tribal courts. 


\section{B. Trailblazing the WAY fOR INDIGENOUS COMMUNITY COURTS}

Throughout the history of Indigenous resistance to colonization in the lands that are now shared with Canada, First Nations have sought to maintain their legal structures, institutions, and processes. As the hold of colonialism loosened and avenues became available to exercise self-governance processes, many First Nations rose to the occasion. With the passage of the Indian Act in 1876, the authority of First Nation Band Councils under the law was limited to eighteen areas of local concern to be exercised through bylaw powers. ${ }^{225}$ Within the narrow powers under the Indian Act, section 107 provided a means for the appointment of Justices of the Peace within reserves. Although not well-documented, there have been panels of First Nation members hearing matters on reserve in a number of provinces.

\section{Section 107 OF the Indian Act: Justices of the PeAcE}

Per section 107, Band Councils were able to appoint justices of the peace to maintain basic law and order on reserve for enforcement of offences under the Indian Act provisions.

The Governor in Council may appoint persons to be, for purposes of this Act, justices of the peace and those persons have the powers and authority of two justices of the peace with regard to

(a) any offence under this Act; and

(b) any offence under the Criminal Code relating to cruelty to animals, common assault, breaking and entering and vagrancy, where the offence is committed by an Indian or relates to the person or property of an Indian. 226

Statistics are lacking on the full range of appointments by Band Councils to exercise the justice of the peace authority. ${ }^{227}$ From 1973 to 1999 , there were approximately 12 justices of the peace appointed in at least three First Nation communities. It is often referred to as the Native Justice of the Peace Program in the sparse literature available. In a 1979 report by Robert Debassige, a discussion of the use of section 107 justices of the peace by Band Councils highlighted issues concerning whether the justices of the peace could enforce provincial law; limitation of authority to swearing information, summonses, and warrants; lack of training; and inadequate funding. ${ }^{228}$ In the conclusion of the report, Debassige recommended a policy manual be developed and wrote "[a] close communication tie with the North American Indian Court Judges Association is advisable as they appear to have the experience in both the training and development of Indian Court Judges." 229

Indian Act, supra note 9, ss 81(1)(a)-(r).

Ibid, s 107.

See Karen Whonnock, “Aboriginal Courts in Canada” (The Scow Institute, 2008) at 4, online: <scowarchive.libraries.coop/library/documents/Aboriginal_Courts.pdf>.

Robert H Debassige, "Section 107 of the Indian Act and Related Issues" (Department of Indian and Northern Affairs, 1979) at 4-8, online: <publications.gc.ca/collections/collection_2017/aanc-inac/R32310-1979-eng.pdf>.

Ibid at 22. 
Since 1999, there have been no appointments approved by Indigenous and Northern Affairs Canada (INAC) and a moratorium was placed on the program in $2004 .{ }^{230}$ Justices of the peace appointed prior to 1999 may still be carrying out their duties. Building on the experiences with the Native Justice of the Peace Program, two Indigenous-based courts have been formed in Canada as trailblazers for other ICCs to follow.

\section{THE AKWESASNE COURT}

With the unique situation of the Akwesasne homelands spanning across areas overlapping with the provinces of Ontario and Quebec, Band members experienced jurisdictional hardships in complying with two sets of provincial laws. As early as 1965, the Mohawk Council of Akwesasne utilized Section 107 of the Indian Act for justices of the peace appointments. ${ }^{231}$ The last appointment occurred in January 1990 for Joyce King who now serves as the Director of the Akwesasne Justice Department. As the Native Justice of the Peace Program ground to a halt, the advice given was for the the Council to have provincially appointed judges from both Ontario and Quebec. ${ }^{232}$ This seemed like an unusually burdensome solution and thus, the Council chose to assert inherent rights in establishing a new process.

Beginning in 2000, the Mohawk Council of Akwesasne began making appointments for justices to the Akwesasne Court due to the end of the Native Justice of the Peace Program and to enforce Akwesasne law across the entire territory. ${ }^{233}$ The justices appointed were required to undergo extensive training at a Montreal law firm on topics such as "criminal court procedure, civil procedure, ethics, due process and judicial fairness." 234 The Akwesasne Court is an example of an inherent right established court with language, culture, and values of paramount importance, blended with the contemporary requirements for judicial forums in Canada. ${ }^{235}$ The Council formalized the Akwesasne Court by law on 12 February 2016 which entered into force in August 2016. ${ }^{236}$

Currently, the Akwesasne Justice Department is comprised of the following: Akwesasne Court, Legal Services, Legislative Services, Akwesasne Community Justice Program, Compliance Program, Conservation Program, Early Release Parole, Ontario Probation, Quebec Probation, and Youth Probation and Reintegration. ${ }^{237}$ In discussing the Akwesasne Justice System, Director King indicated that there were four common themes: societal order, standards of conduct, protection of members, and provision of stability and certainty. In addition, there are principles unique to the Akwesasne community, such as the kinship or clan system; collective rights; principles of peace, strength, and the good mind; non-

See Ell v Alberta, 2003 SCC 35. After the reform of the Alberta requirements for justices of the peace, the Supreme Court of Canada upheld the new requirements which resulted in termination of a number of positions not meeting the requirements.

231 Presentation by Director Joyce King in "Aboriginal Justice Systems Conference," supra note 57 at 1h:33m:40s-1h:36m:44s, $1 \mathrm{~h}: 47 \mathrm{~m}: 15 \mathrm{~s}-1 \mathrm{~h}: 55 \mathrm{~m}: 27 \mathrm{~s}$.

Ibid.

Ibid.

Ibid.

Ibid.

Mohawk Council of Akwesasne, Akwesasne Tekaia'torehthà:keKaianerénhsera (Akwesasne Court Law), Kaiahnehronshera iehiontakwa No 2016-01 (12 February 2016), online: <webdev.akwesasne.ca/ wp-content/uploads/2017/07/mcr-atk-acl2016.pdf>. 
adversarial interactions; and restoration or removal of individuals. ${ }^{238}$ Thus, there is a restorative justice approach to court processes.

There continue to be ongoing issues that require cross-jurisdictional resolution due to the overlapping of the Akwesasne lands with the provinces of Ontario and Quebec and with the federal government. At present, the Akwesasne Court has limited criminal jurisdiction, but is recognized by the federal government in the Family Homes on Reserves and Matrimonial Interests or Rights Act as empowered to enforce Akwesasne law. ${ }^{239}$ A mechanism for the recognition of Akwesasne Court orders in Ontario and Quebec courts is lacking. Despite the reluctance of external governments to fully embrace the Akwesasne Court's jurisdiction and orders, the justices continue to maintain law and order based on the principles that have governed the Akwesasne peoples since time immemorial.

\section{THE COURT OF KAHNAWÀ:AKE}

Similarly, the Court of Kahnawà:ke began operation through the justices of the peace system and currently has two appointees in place. ${ }^{240}$ There are two sessions regularly held within the court system: Criminal Court and Traffic Court. ${ }^{241}$

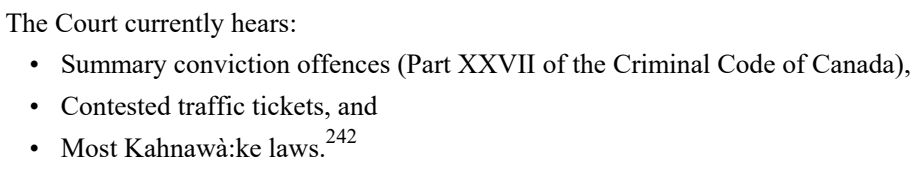

As a resource for the community, all of the Kahnawà:ke laws are published online. ${ }^{243}$ The diminishment of the Native Justices of the Peace Program was one of the impetuses for implementing a justice system based on Kahnawà:ke law. ${ }^{244}$

In 2015, the Kahnawà:ke Justice $A c t^{245}$ was enacted to provide a blueprint for the Kahnawà:ke Justice system with processes for appointment of judges and oversight of four different judicial forums: (1) Skén:nen Aonsón:ton (Alternative Dispute Resolution); (2) Administrative Tribunals; (3) Court of Kahnawà:ke; and (4) Kahnawà:ke Court of Appeal. ${ }^{246}$ Head of the Justice Department, Kevin Fleischer, is tasked with implementing the law and bringing each part of the processes into reality. ${ }^{247}$ The justice system is intended to provide access to justice for the Kahnawà:ke community and to replace the mistrust of external courts

King, supra note 231.

SC 2013, c 20, s 7.

See Kevin Fleischer, "The Court of Kahnawà:ke \& Kahnawà:ke Justice System” (15 February 2018) at 3, online: $<\mathrm{https} / / / \mathrm{www} . c e r p . g o u v . q c . c a /$ fileadmin/Fichiers_clients/Documents_deposes_a_la Commission/P-365.pdf>

See Mohawk Council of Kahnawà:ke, "Court of Kahnawà:ke," online: <www.kahnawake.com/org/ court/>.

Fleischer, supra note 240 at 8.

See Kahnawà:ke Community Decision Making Process, "Legislative Listing," online: <www. kahnawakemakingdecisions.com/legislation/>.

Interview of Kevin Flesicher (7 September 2018).

KRL, c J-1 (2015).

Ibid, ss 6-9.

Interview of Kevin Flesicher, supra note 244. 
with justice at home. ${ }^{248}$ Along this line, individuals have the ability to choose traditional forums to resolve disputes with talking circle and mediation processes, rather than resort in the first instance to adversarial courtrooms. ${ }^{249}$

The Kahnawà:ke Justice System structure is a burgeoning system guided by First Nation law. Due to the size of the initiative, it will require ongoing planning, negotiation with external judicial forums, and will be gradually implemented. ${ }^{250}$ This then is another example of inherent right as the basis for establishing an Indigneous community court guided by Indigenous law.

\section{SELF-GOVERNMENT AGREEMENTS AND MODERN DAY TREATY-MAKING}

The Canadian government has engaged in the recent process of entering into selfgovernment agreements on a selective basis. The agreements require lengthy negotiations and are viewed as not constitutionally protected under section 35(1) of the Constitution Act, 1982, which affirms existing Aboriginal rights. Two examples of self-government agreements which include judicial forums are from the Council of Yukon First Nations and the Sioux Valley Dakota Nation.

From the Council of Yukon First Nations, the Teslin Tlingit Justice Agreement in 2011 was the first of its kind to come into effect. ${ }^{251}$ The Agreement provides for the establishment of a Peacemaker Court based on traditional Teslin Tlingit principles and processes for dispute resolution. ${ }^{252}$ The Agreement empowers the First Nation to enforce its own laws, appoint adjudicators to oversee prosecutions of violations of those laws, and to review as necessary actions of First Nation officials and administrative bodies. ${ }^{253}$ The Teslin Tlingit contemporary justice system will be "guided by the principles of Ha Kus Teyea which embody respect, fairness, integrity, honesty, responsibility and accountability." 254 The Peacemaker Court operates on two levels - Stage One involving a consent-based dispute resolution process and Stage Two for all other matters to be adjudicated with processes open to the public and with permanent public records maintained. ${ }^{255}$

Provisions of the Teslin Tlingit Justice Agreement include the ability of the Peacemaker Court to transfer appropriate matters to the Small Claims Court of the Yukon, the Territorial Court of the Yukon, or the Supreme Court of the Yukon. ${ }^{256}$ Upon application for transfer

See The Administration of Justice Agreement Among Teslin Tlingit Council and Her Majesty the Queen in Right of Canada and the Government of Yukon, 21 Feburary 2011, online: <www.ttc-teslin.com/ administration-of-justice-agreement.html> [Teslin Tlingit Justice Agreement]. Ibid.

Ibid.

Ibid, s 2.0 .

Ibid, s 5.9 .

Ibid, s 5.12 .
} 
from the Small Claims Court or the Territorial Court, an appropriate matter may be timely transferred to the Peacemaker Court. ${ }^{257}$ Appeals from the Peacemaker Court are heard by the Supreme Court of the Yukon and the Teslin Tlingit reserve the right to appoint "a friend of the court to assist in the interpretation of Teslin Tlingit Law." ${ }^{258}$ As the Court begins operation, it may be useful to consider an appellate procedure that does not bring the matters heard in the Peacemaker Court to the external Canadian court system.

On 30 August 2013, the Sioux Valley Dakota Nation signed off on a Governance Agreement $^{259}$ and Tripartite Governance Agreement ${ }^{260}$ with Canada and the province of Manitoba that included provisions for the establishment of a court system, laws, and justice framework. ${ }^{261}$ Under section 53.02 of the Goverance Agreement, the provisions for an enabling law are set forth to establish a Sioux Valley Dakota Nation (SVDN) Court. ${ }^{262}$ While the Court is to have authority to prosecute violations of SVDN laws and adjudicate civil actions under those same laws, the agreement provides for the right of appeal to the Manitoba Court of Queen's Bench and to the Manitoba Court of Appeal. ${ }^{263}$ As judicial experience is gained through the operation of the SVDN justice system, the First Nation may consider seeking revision to the Governance Agreement for its own appellate procedure and forums.

Canada has also engaged in modern treaty negotiations as evidenced in the Nisga'a Final Agreement which came into effect on 11 May $2000 .{ }^{264}$ Within the provisions of the Final Agreement, a Nisga' a Court is contemplated pending approval by the Lieutenant Governor of Council of the "structure, procedures, and method of selection of judges" 265 and an appeal structure through provincial and federal court. ${ }^{266}$ Key features of the proposed court include the ability to "apply traditional Nisga' a methods and values, such as using Nisga'a elders to assist in adjudicating and sentencing, and emphasizing restitution." ${ }^{267}$ The Nisga'a Court has the ability to review the Nisga'a Public Institution's administrative decisions, provide prosecution through adjudication of Nisga'a laws, and provide "adjudication of disputes arising under Nisga'a laws between Nisga'a citizens on Nisga'a lands that would be within the jurisdiction of the Provincial Court of British Columbia if the disputes arose under provincial law." ${ }^{268}$ Expanded jurisdiction is available with the consent of parties in civil matters. ${ }^{269}$

Ibid, s 5.13 .

Ibid, s 6.3 .

Bill 48, The Sioux Valley Dakota Nation Governance Act, 3rd Sess, 40th Leg, Manitoba, 2014, Explanatory Note, online: $<$ https://web2.gov.mb.ca/bills/40-3/pdf/b048.pdf $>$.

Ibid.

See Sioux Valley Dakota Nation, “A Self-Governing Dakota Nation” (18 May 2016), online: <https:// www.svdngovernance.com/governance/a-self-governing-dakota-nation/>.

See Governance Agreement Between Sioux Valley Dakota Nation and Her Majesty the Queen in Right of Canada, 30 August 2013, s 53.02, online: <https://www.gov.mb.ca/inr/resources/pubs/sioux\%20 valley $\% 20$ dakota $\% 20$ nation $\% 20$ tripartite $\% 20$ agreement $\% 20$ (aug\%202013).pdf $>$. Ibid, ss 53.04(3), 53.05(6).

See Nisga'a Lisims Government, "About - Accomplishments and Benefits of Nisga'a Treaty," online: $<$ www. nisgaanation.ca/about-accomplishments-and-benefits-nisgaa-treaty>.

See Nisga'a Final Agreement, 27 April 1999, ch 12, ss 34-36.

Ibid, ss 45-48.

Ibid, s 41(d).

Ibid, $\mathrm{s} 38$.

Ibid, s 39 . 
In summary, the determination of First Nations to establish their own judicial forums under Indigenous laws and authority is evident throughout the history of interaction with Canada. Through various means, judicial systems are beginning to take hold under Indigenous authority based upon Indigenous values, legal principles, and concepts of justice. Many of these examples stem from the desire to leave behind the oppressive force of the Indian Act for another way forward. ${ }^{270}$ Unfortunately, there remain restraints, unresolved issues, and seeming reluctance on the part of the federal government and provincial governments to recognize the inherent sovereignty and authority of these re-emerging justice systems. This reluctance is apparent in the lack of mechanisms for recognizing Indigenous court orders and judgments; the curtailing of the right of appeal to Canadian provincial and federal courts; and the lack of funding for judicial programs.

\section{FUNDING AND SUPPORT FOR INDIGENOUS COMMUNITY COURTS}

The underfunding of programs and governmental services on First Nation reserves and for First Nation peoples living in urban settings has been an ongoing source of frustration in Indigenous Canada. An economic analysis on the current criminal law overincarceration of Aboriginal peoples and the cost to the Canadian government in foster care payments for the mass removals of Aboriginal children would likely reveal that funding ICCs and community services would be far less in the end. Canada would need to commit to permanent and longterm funding for ICCs to make a difference in First Nation peoples' lives. As reported in a news article from 2018, "[a]ccording to the Parliamentary Budget Officer, it costs upwards of $\$ 343,810$ to incarcerate one woman for a year and $\$ 223,687$ to incarcerate a man." ${ }^{271}$ In terms of foster care costs, the Government of Canada reported that for First Nations Child and Family Services the average maintenance cost for a child in care was $\$ 41,353.10$ per child in 2016-2017. ${ }^{272}$ These costs would be better spent supporting First Nations' efforts on providing judicial services and community programs to care for their own peoples.

Second, there would need to be champions and allies who support the development of Indigenous community courts. Those with judicial experience on the provincial and federal benches may be best suited to assist in the early stages of setting up the court systems as called upon by First Nation governments. Territoriality and competitive attitudes would be harmful in the nascent stages of the development of these systems. As explained below from

See e.g. Sioux Valley Dakota Nation, supra note 261 (“[t]hrough maintaining a consistent vision of former leaders, Sioux Valley Dakota Nation has taken the initiative to not be the subject of Indian Act policy, and instead be a Dakota Nation which is self-governing by the Dakota Oyate under SVDN law").

271 See Vicki Chartrand, "Broken System: Why is a Quarter of Canada's Prison Population Indigenous?" The Conversation (18 February 2018), online: <http://theconversation.com/broken-system-why-is-aquarter-of-canadas-prison-population-indigenous-91562> ("[a]ccording to the Parliamentary Budget Officer, it costs upwards of $\$ 343,810$ to incarcerate one woman for a year and $\$ 223,687$ to incarcerate a man").

272 See First Nations Child and Family Services (28 February 2019), online: <www.aadnc-aandc.gc. ca/eng/1100100035204/1100100035205>; see also Tracy Sherlock, "Disproportionate Number of Aboriginal Children in Foster Care," Vancouver Courier (22 November 2017), online: <www. vancourier.com/opinion/disproportionate-number-of-aboriginal-children-in-foster-care-1.23101923 > (noting foster care payments can reach $\$ 3,000$ per month). 
the US state and tribal court perspective, court systems have choices in the levels of support that can be offered.

\begin{abstract}
There are five levels of interaction that can exist between tribal courts and state courts. The first level is no cooperation - efforts to help the other operate are absent. The second is a minimal level of cooperation efforts that provide some help to the other court to operate more efficiently. The third level is full cooperation - the organizations work together so that they each operate at maximum efficiency, but their operations are completely independent. The fourth level is collaboration - at this level there is interaction whereby the courts not only operate at maximum efficiency themselves, but actively seek to help the other court operate better through some interactive efforts. The fifth and final level is co-creation - at this level the courts are working together so that they can maximize the results for both courts through joint efforts at all possible levels. ${ }^{273}$
\end{abstract}

Reversing colonial attitudes of non-Indigenous lawyers and judges towards Indigenous peoples would need to occur for support and collaboration with ICCs. This work is advanced by the Truth and Reconciliation Commission's Calls to Action and in particular Call to Action 27 directed at cultural competency for lawyers. ${ }^{274}$ Similarly, Call to Action 28 is directed at law schools to ensure that future lawyers receive adequate cultural competency training and background on Aboriginal-Crown relations, treaties, and the UNDRIP. ${ }^{275}$

\title{
D. Swinging the Pendulum in Canada TO SUPPORT FirSt NATION SOVEREIGNTY
}

The British Crown entered into treaty relationships with First Nations. The government of Canada inherited the obligations, duty, responsibilities, and relationships under those treaties. ${ }^{276}$ Canada continued to reach out to First Nations as a treaty party. This early time period of treaty-making from 1871 to 1921 can be viewed as a Canadian Indigenous policy era of sovereign-to-sovereign relations. The pendulum then swung to the destruction of First Nation sovereignty with the enactment of the Indian Act of $1876 .{ }^{277}$ There has been no major announced shift in Canadian Indigenous policy since the passage of that law.

Honourable Korey Wahwassuck, The Honourable John P Smith \& The Honourable John R Hawkinson, "Building a Legacy of Hope: Perspectives on Joint Tribal-State Jurisdiction" (2010) 36:2 Wm Mitchell L Rev 859 at 866-67.

See TRC, Vol 6, supra note 5 at Recommendation 27:

We call upon the Federation of Law Societies of Canada to ensure that lawyers receive appropriate cultural competency training, which includes the history and legacy of residential schools, the United Nations Declaration on the Rights of Indigenous Peoples, Treaties and Aboriginal rights, Indigenous law, and Aboriginal-Crown relations. This will require skills-based training in intercultural competency, conflict resolution, human rights, and anti-racism. Ibid at Recommendation 28 .

276 See John Borrows,"Wampum at Niagara: The Royal Proclamation, Canadian Legal History, and SelfGovernment" in Michael Asch, ed, Aboriginal and Treaty Rights in Canada: Essays on Law, Equality, and Respect for Difference (Vancouver: UBC Press, 1997) 155 at 156-65. 
Figure 2: Depicting the Canadian Government's

INDIGENOUS POLICY From SUPPORTING FIRST NATION

SOVEREIGNTY TO DESTRUCTION OF FIRST NATION SOVEREIGNTY

\begin{tabular}{|l|l|}
\hline \multicolumn{1}{|c|}{ Supporting First Nations sovereignty } & \multicolumn{1}{|c|}{ Destruction of First Nations Sovereignty } \\
\hline $\begin{array}{l}\text { Sovereign-to-Sovereign Relations: Treaties } \\
1871 \text { to } 1921\end{array}$ & \\
\hline & $\begin{array}{l}\text { Indian Act and Assimilation } \\
1876-\end{array}$ \\
\hline
\end{tabular}

Rather, there have been isolated and individuated steps toward supporting First Nation sovereignty through modern treaty-making efforts or possibly land claim settlement agreements, but there has been no national policy announced that refutes the assimilationist destructive policies of the late 1800s. In fact, the crisis in foster care placements has been called the new Indian residential school system and the overincarceration of Aboriginal peoples has continued the policy of forced assimilation or suffer the consequences. To swing the pendulum towards support for First Nation sovereignty will require a major federal enactment announcing a new policy with a focus on self-governance and self-determination for First Nations as nations.

Compared to the more active pendulum swings in US Indian policy as detailed in Figure 1 above, there are both positive and negative policy eras that are absent in the Canadian Indigenous experience. The US Indian policy swing to support Indian self-government with the enactment of the Indian Reorganization Act of 1834 is noticeably lacking in the Canadian experience. The northern Indigenous peoples also did not face the Termination Era of US Indian policy, although the White Paper of 1969 espoused very similar propositions. ${ }^{278}$ The final swing to present day in the US is Indian self-determination which has led to an exponential development of tribal-led initiatives, economic development, educational institutions, and positive societal impacts. This is now the challenge that lies before First Nations, allies, and advocates: to swing the pendulum towards a Canadian governmental policy to support First Nation sovereignty through a federal law that will withstand administration changes and allow First Nations to truly self-govern.

From the Royal Commission on Aboriginal People, a proposed nation model of government was offered. "In each area of government responsibility, an Aboriginal nation would have powers and authorities in respect of law making (legislative); administration and policy making (executive); and interpretation, application and enforcement of law (judicial)." ${ }^{, 79}$ white paper on Indian policy, which sought to terminate the federal government's special relationship with Aboriginal peoples" at 202).

279 Report of the Royal Commission on Aboriginal Peoples: Restructuring the Relationship, vol 2 (Ottawa: Canada Communication Group, 1996) at 241. 


\section{Conclusion}

One of the pillars of self-government is the ability to resolve disputes peaceably and provide organization to society. In this article, the proposal for the development of ICCs governed by First Nation law and authority is offered as a means to resolve the current crisis of overincarceration of Aboriginal peoples in provincial court systems and to stem the tide of removal of increasing numbers of Aboriginal children from their homes and into foster care under the supervision of provincial courts. There are burgeoning ICCs in Canada that serve as trailblazers for others to follow, but there is still much work to be done to fully support these new justice systems. By observing the establishment of US tribal courts since 1934, a model and willing expertise is available to assist in bringing this proposal to fruition.

Justice for First Nations will not occur in the courts of the colonizers. As Canada seeks to shift into a new era by embracing the Truth and Reconciliation Commission's Calls to Action and the UNDRIP, a loosening of colonial control is necessary. The attitudes and legacy of colonization must be eradicated to allow First Nations to realize justice in their own communities and for their own peoples.

There is currently underway a resurgence of Indigenous legal knowledge, expertise, and institutions. Indigenous peoples in Canada have sounded the cry that change will happen as they are "Idle No More."."280 people to join in a peaceful revolution, to honour Indigenous sovereignty, and to protect the land and water"). 
[this page is intentionally blank] 